\title{
Accretion, Structure and Hydrology of Intermediate Spreading-Rate Oceanic Crust from Drillhole Experiments and Seafloor Observations
}

\author{
PHILIPPE A. PEZARD ${ }^{1}$, ROGER N. ANDERSON ${ }^{2}$, WILLIAM B. F. RYAN ${ }^{3}$, \\ KEIR BECKER ${ }^{4}$, JEFFREY C. ALT ${ }^{5}$, and PASCAL GENTE ${ }^{6}$ \\ ${ }^{1}$ Département de Génie Océanique, Institut Méditerranéen de Technologie, 13451, Marseille, France \\ ${ }^{2}$ Borehole Research Group of the Lamont-Doherty Geological Observatory, and Department of Geological Sciences, Columbia University, \\ Palisades, New York 10964, U.S.A. \\ ${ }^{3}$ Marine Geology and Geophysics of the Lamont-Doherty Geological Observatory, and Department of Geological Sciences, Columbia \\ University, Palisades, New York 10964, U.S.A. \\ ${ }^{4}$ Rosentiel School of Marine and Atmospheric Sciences, Division of Marine Geology and Geophysics, 4600 Rickenbacker Causeway, Miami, \\ Florida 33149, U.S.A. \\ ${ }^{5}$ University of Michigan, Department of Geological Sciences, Ann Arbor, Michigan 48109, U.S.A. \\ ${ }^{6}$ Université de Bretagne Occidentale, 6 Avenue Le Gorgeu, 29283, Brest, France
}

(Received 25 September, 1991; accepted 11 October 1991)

Key words: Accretion model, oceanic crust, downhole measurements, hydrothermalism, mid-ocean ridge.

\begin{abstract}
Downhole measurements recorded in the context of the Ocean Drilling Program in Hole 504B, the deepest hole drilled yet into the oceanic crust, are analyzed in terms of accretion processes of the upper oceanic crust at intermediate spreading-rate. The upper part of the crust is found to support the non steady-state models of crustal accretion developed from seafloor observations (Kappel and Ryan, 1986; Gente, 1987). The continuous and vertical nature of borehole measurements provides stratigraphic and structural data that cannot be obtained solely from seafloor studies and, in turn, these models define a framework to analyze the structural, hydrological, and mineralogical observations made in the hole over the past decade.

Due to the observed zonation with depth of alteration processes, and its relation to lava morphologies, the 650 -m-thick effusive section penetrated in Hole $504 \mathrm{~B}$ is postulated to be emplaced as the result of two main volcanic sequences. Massive lava flows are interpreted as corresponding to the onset of these sequences emplaced on the floor of the axial graben. The underlying lava made of structures with large porosity values and numerous cm-scale fractures is thus necessarily accreted at the end of the previous volcanic episode. On top of such high heterogeneous and porous intervals, the thick lava flows constitute crustal permeability barriers, thereby constraining the circulation of hydrothermal fluids.

Accreted in the near vicinity of the magma chamber, the lower section is that exposed to the most intense hydrothermal circulation (such as black smokers activity). Once capped by a massive flow at the onset of the second volcanic phase, the lower interval is hydrologically separated from ocean-waters. A reducing environment develops then below it resulting, for example, in the precipitation of sulfides. Today, whereas the interval corresponding to the first volcanic episode is sealed by alteration minerals,
\end{abstract}

the second-one is still open to fluid circulation in its upper section. Thus, upper part of the volcanic edifice is potentially never exposed to fluids reaching deep into the crust, while the lower one is near the ridge axis.

Considering that most of the extrusives are emplaced within a narrow volcanic zone, the first unit extruded for a given vertical cross-section is necessarily emplaced at the ridge-axis. In Hole 504B, the 250-m-thick Transition Zone from dikes to extrusives is interpreted as the relict massive unit flooding the axial graben at the onset of the first volcanic sequence, and later ruptured by numerous dikes. Further from the axis, the same massive unit constitutes a potential permeability cap for vertical crustal sections accreted earlier. Also, the upper 50 meters of the basement might be considered as the far-end expression of massive outpours extruded near the ridge-axis.

\section{Introduction}

For the past thirty years, tremendous resources have been devoted to the study of the main locus of active volcanism on earth, mid-ocean ridges (MOR). Over sixty percent of the earth's surface is created at oceanic spreading centers, as magmas generated in the upper mantle in response to decompression are cooled to form the oceanic crust. This accretion process involves complex interplays of volcanic, tectonic, and hydrothermal processes, all of which are still poorly understood. The interaction of seawater with magmatically heated crustal rocks generates hydrothermal venting along the mid-ocean ridge crest and within ridge flanks (Lister, 1972, 1980; 
Williams et al., 1974; Anderson et al., 1977; Fehn et al., 1983; Morton and Sleep, 1985). As a consequence, due to the great length of MOR complexes, the chemistry and mass balance of the world's ocean are affected by reactions with the basaltic crust (Sleep and Woolery, 1978; Edmond et al., 1979). The study of MOR structures and processes is thus of prime importance for the understanding of the earth as a regulated system.

Over the last decade, a variety of morpho-structural, geophysical, and geochemical investigations have led to a more detailed description of MOR at various scales (Macdonald, 1983; Gente, 1987). High resolution mapping of the sea-floor, in particular, has showed that medium-to-fast spreading ridges such as those found in the eastern Pacific are segmented at a 50 -to- $150 \mathrm{~km}$ scale. This segmentation appears primarily in the volcano-tectonic morphology of the ridge crest (Macdonald et al., 1984; Kappel and Ryan, 1986; Gente, 1987; Macdonald and Fox, 1988) and, to some extent, in the axial hydrothermal activity (Haymon and Koski, 1987; Nehlig and Juteau, 1988), subsurface structure (Macdonald and Fox, 1988; Vera, 1989), and lava composition (Langmuir et al., 1986; Klein and Langmuir, 1987).

In addition to the well-documented age-dependent variations perpendicular to ridge-strike, along-strike and temporal variations in the volcano-tectonic activity have contributed to the construction of more complex models of MOR processes. In the former, freshly-accreted crust is supposed to migrate away from the spreading axis and out of the rift valley, being tectonically reorganized as it moves along the flanks of the axial structure. Instead, the latter stresses the cyclic nature of this otherwise steadystate volcano-tectonic process. From a two-dimensional understanding initially derived mostly from the analysis of topographic profiles recorded orthogonal to ridge-strike (Lewis, 1979; Macdonald, 1983), the concept of MOR structures has consequently evolved now to more sophisticated, three-dimensional models.

However, the stratigraphy of MOR volcanic edifices cannot be studied solely from dredging campaigns or sea-floor analyses and remains to be included as input to these accretion models. The subsurface vertical dimension may only be sampled by looking at scarps or by drilling the oceanic base- ment, which has been one of the most important objectives of the Deep-Sea Drilling Project (DSDP) and of the Ocean Drilling Program (ODP) in the past twenty years or so. Nevertheless, only one drillhole has yet succeeded in penetrating the entire extrusion section of the upper crust. This hole is referred to as DSDP Hole 504B and is located in the eastern equatorial Pacific (Figure 1), $200 \mathrm{~km}$ south of the Costa Rica rift which constitutes the easternmost segment of the Galapagos Spreading Center (GSC) (Lonsdale, 1977; Lonsdale and Klitgord, 1978; CRRUST, 1982). This deep hole has been drilled and instrumented by five successive sea-going campaigns: DSDP legs $69,70,83,92$, and ODP leg 111.

Beneath $275 \mathrm{~m}$ of sediments, Hole 504B penetrates 1287.8 meters into $5.9 \mathrm{Ma}$ basaltic basement of the Nazca Plate (Figure 2), sampling the sheeted-dike complex elsewhere described only in ophiolite studies (Kidd, 1977; Moores, 1982). All other efforts to drill MOR structures have reached no deeper than $600 \mathrm{~m}$ into the igneous crust. Consequently, Hole 504B stands today as the sole direct evidence of the layered structure of the upper oceanic crust (Cann, 1968; Christensen and Salisbury, 1975; Houtz and Ewing, 1976). The volcanic column sampled at Site 504 therefore constitutes a unique opportunity to analyze accretion processes as a time-sequence and in terms of submarine volcanic eruptions that built it.

Such an approach was followed in the past by Hyndman and Salisbury (1983) with the analysis of resistivity data recorded in Hole 395A, which unfortunately samples only part of the volcanic edifice (Figure 3). Hole 395A is located in $7.3 \mathrm{ma}$ crust of the Mid-Atlantic Ridge (MAR), and penetrates 571.0 meters of basaltic basement overlain by 93.0 meters of sediments (Melson and Rabinowitz, 1979). The sequences of increasing electrical resistivity (or decreasing porosity) with depth outlined by a dashed line in Figure 3 were found to match magma fractionation episodes and interpreted as eruptive cycles by Hyndman and Salisbury (1983). Each cycle was hence proposed to represent a single eruptive event at the ridge axis. These cycles start at the bottom with high electrical resistivity values (or low porosity) associated with the eruption of massive flows, then gradually evolve to low electrical resistivity (high porosity) pillows. The breccias and talus 


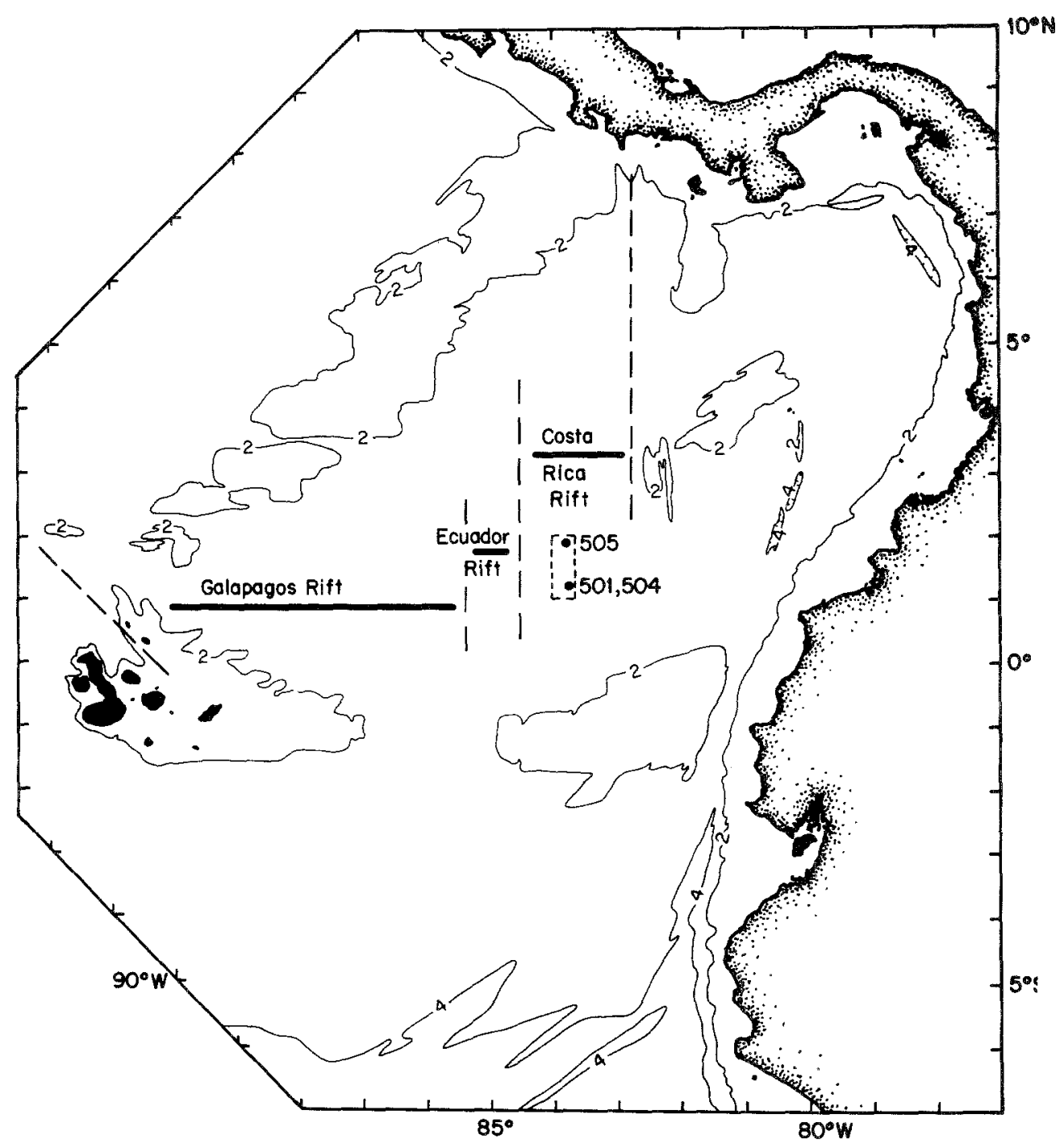

Fig. 1. Location of Site 504 on the south flank of the Costa Rica rift, Panama basin. Bathymetry from Lonsdale and Klitgord (1978). Contour interval $=2000 \mathrm{~m}$.

observed toward the top of each cycle represent the last phase of the eruptive sequence, with an abrupt change in physical properties corresponding to the onset of the next volcanic cycle. These increasing porosity trends are proposed to represent sequences of viscosity decrease of the magma source and constitute an excellent basis for the study of the volcanic accretation at the MAR. In particular, it might be noticed that the thickness of the proposed cycles decreases with decreasing age (or decreasing depth), the thickest unit being observed at the base of the penetrated interval. In addition, the presence of breccias and talus intervals at the ends of these cycles is emphasized by the temperature logs recorded during
DSDP Let 45, 78B and ODP Leg 109 (Figure 3), showing a downward fluid-flow into several permeable intervals at this particular site (Kopietz et al., 1989).

The crustal section penetrated by Hole 504B was accreted at a faster spreading-rate (about $7.0 \mathrm{~cm} \mathrm{yr}^{-1}$ at full-rate) than on the MAR for Hole $395 \mathrm{~A}$ (about $2.0 \mathrm{~cm} \mathrm{yr}^{-1}$ at full rate). Only one permeable interval was discovered (Anderson and Zoback, 1982; Becker et al., 1989), and the resistivity data generally do not resemble the characteristic 'saw-tooth' signature outlined by Hyndman and Salisbury (1983) in Hole 395A (Figure 3). For example, pillow units have generally a resistivity of $10.0 \Omega \mathrm{m}$ 


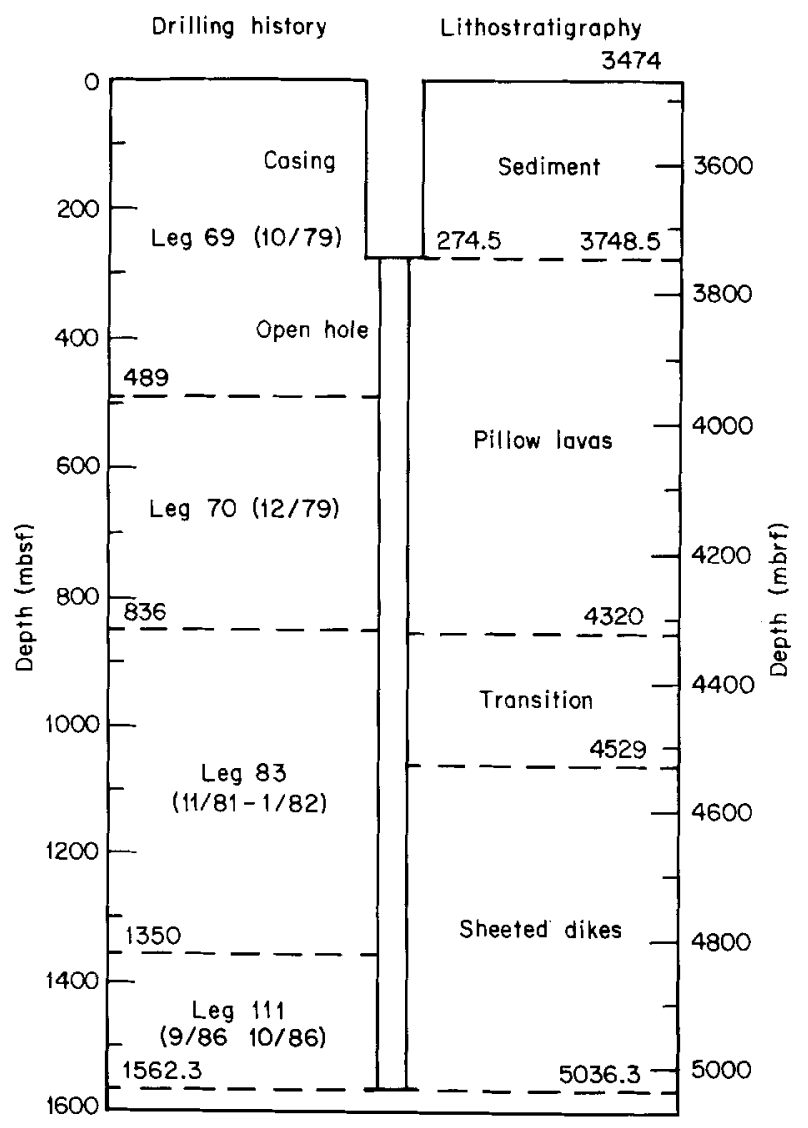

Fig. 2. Schematic of Hole 504B drilling history and lithostratigraphy through Leg 111 (from Becker et al., 1989). The depth is given both in meters below sea floor and in meters below drill floor.

(Pezard and Anderson, 1989), somewhat modulated by the degree of fracturing and associated alteration (Figure 4). However, sequences of massive to thin flows of decreasing thickness and resistivity (increasing porosity) with increasing time (decreasing age and/or depth), and that might elsewhere be compared to the cycles of Hole 395A, are observed (Figure 4). Such sequences could be interpreted as well in terms of accretion processes at the ridge axis. On the basis of 25 years of detailed studies of MOR structures and processes from seafloor analyses and crustal drilling, a model of crustal accretion at medium spreading-rate is described in this manuscript. This model is developed from the analysis of continuous measurements of electrical resistivity made in Hole 504B.

The study of electrical properties of rocks and minerals is that of the description of composite media in terms of mixing laws (Shankland and Waff, 1974; Olhoeft, 1981). Whereas the intrinsic notion of physical property (such as density or electrical resistivity) assumes at a given scale statistical homogene- ity (or isotropy) of the analyzed material, geological systems are often inhomogeneous and anisotropic in nature for constructional, hydrothermal, or tectonic reasons (Keller and Frischknecht, 1966; Hill, 1972). There are consequently a large number of unsolved problems associated with the analysis of electrical properties of rocks which, due to an extreme sensitivity and in spite of their complexity, offer some of the most accurate means to probe both the largeand small-scale structures of rock formations. In order to illustrate these points, electrical properties at low frequencies (less than one $\mathrm{kHz}$ ) are known to respond to the nature of the rock matrix, to the saturating-fluid chemistry, to oxidation-reduction and clay-organic reactions, cation exchange and corrosion processes, fluid motion and chemical concentration gradients. In addition, most of these processes are strongly dependent upon pressure, temperature and frequency of the electromagnetic signal, which provides additional means to study the internal structure of rocks. As a consequence, variations 

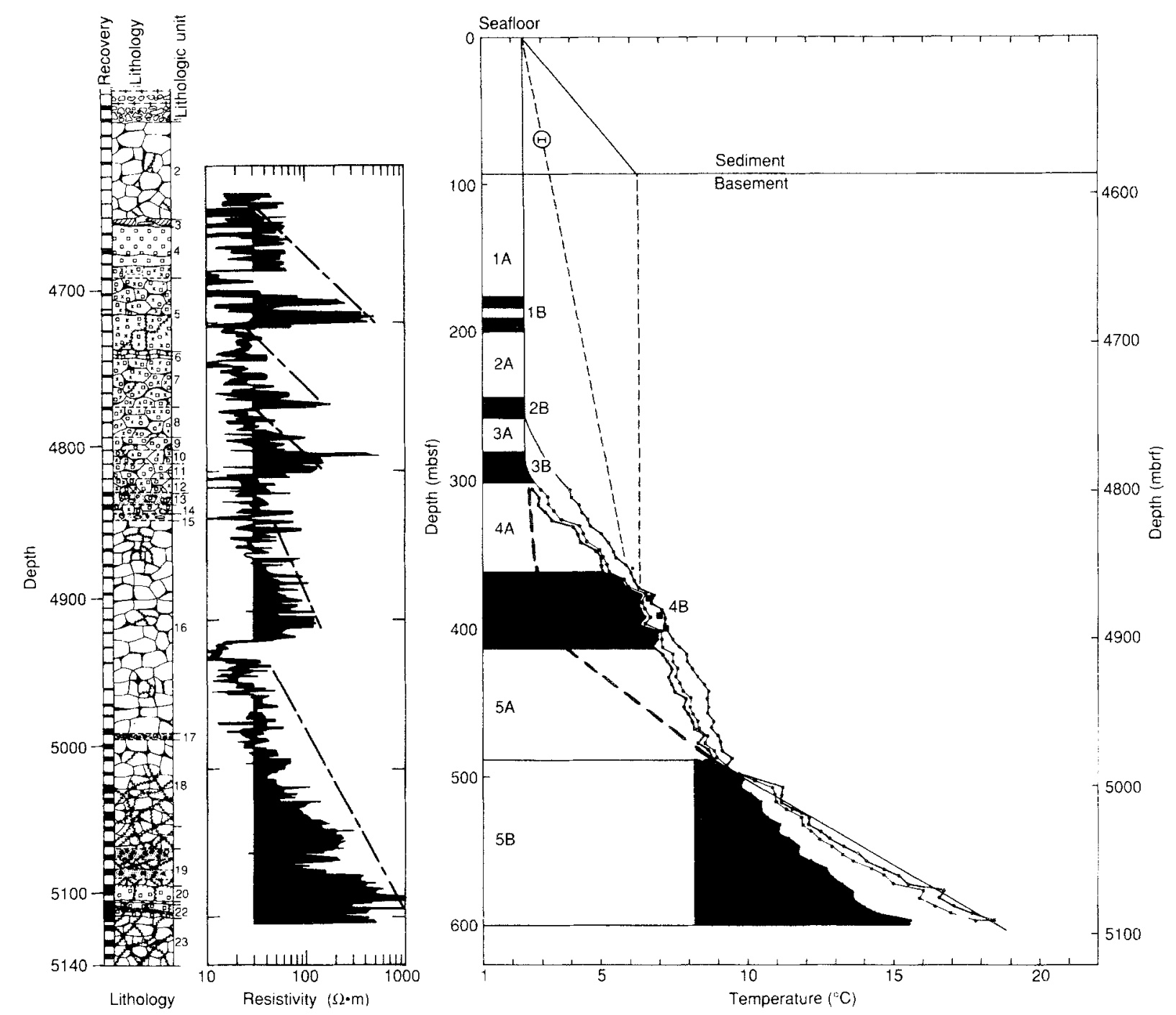

Fig. 3. Lithology from core description, electrical resistivity log, and temperature logs recorded in Hole 395A during Leg 78A. The dashed lines represent the interpreted magmatic cycles of Hyndmann and Salisbury (1983). The shaded areas represent the sections of the crust with in situ resistivities measured in excess of $30.0 \Omega \mathrm{m}$. The depth is given both in meters below sea floor and in meters below drill floor

over 24 orders of magnitude for electrical resistivity have been observed in the Earth (Parkhomenko, 1967; Olhoeft, 1981).

Historically, electrical sounding has been used to detect the presence of conductive anomalies in subsurface such as massive sulfides and coal (Schlumberger, 1920), or resistive fluids such as hydrocarbons in the pore space of sedimentary rocks. With the advent of plate tectonics in the 1960 s, it was shown that the earth's crust is submitted not only to lithostatic pressure and mantle heatflow, but also to large-scale horizontal forces. The earth's crust is also permeated by fluids with varying physical and chemical nature, all of which affect the in situ physical and chemical properties of the fluidrock assemblage. As the analytical techniques to measure physical properties of rocks were defined in the laboratory over the past two hundred years, the in situ measurements appear today as indispensable to analyze active geological processes. The continuous resistivity profiles recorded in DSDP Hole 504B are used here to describe the structure of the upper oceanic crust, and develop an accretion model for intermediate spreading-rate mid-ocean ridges. The 

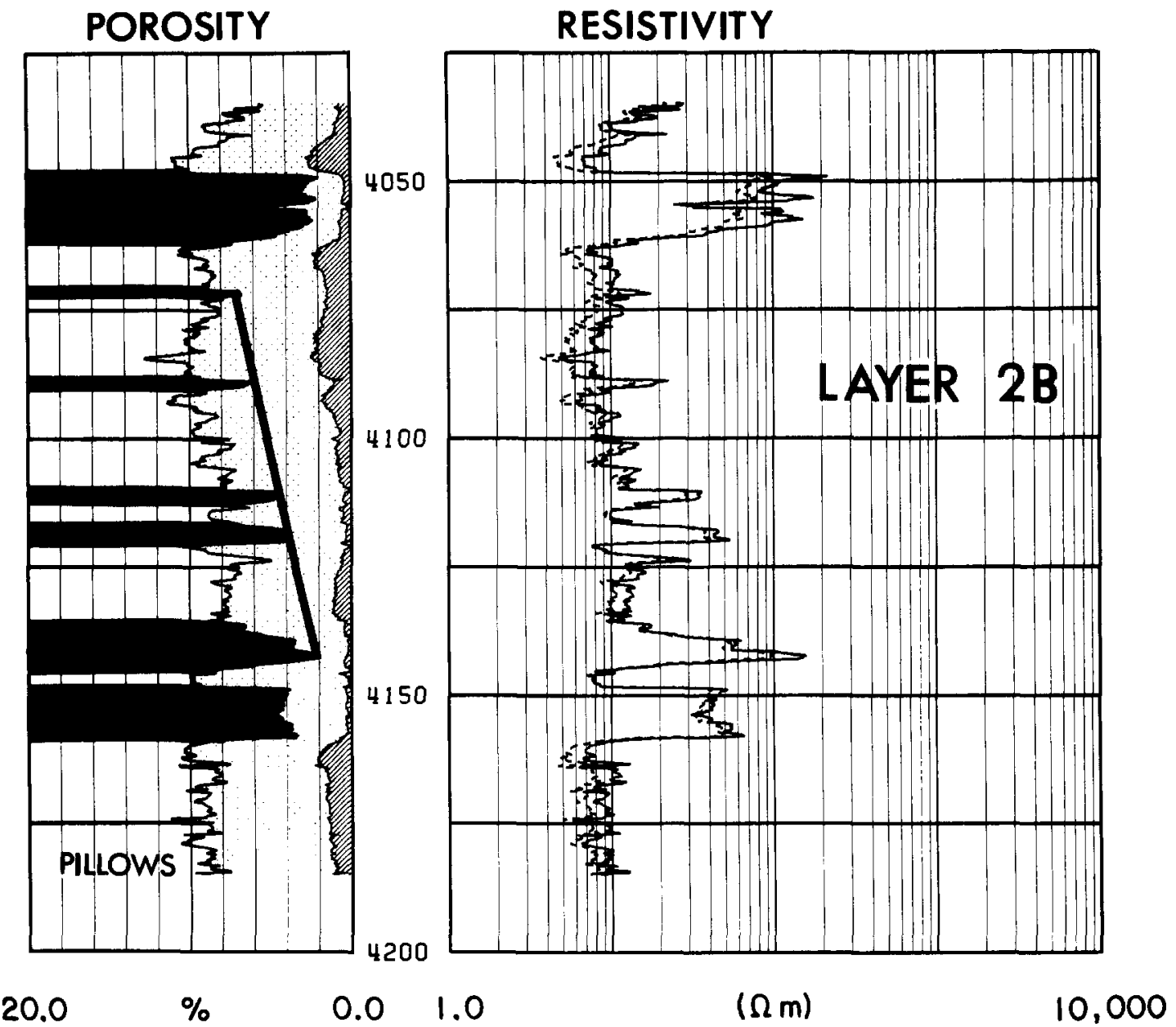

20.0

$\%$

0.0

1.0

$(\Omega \mathrm{m})$

10,000

Fig. 4. Electrical resistivity measurements recorded in Layer 2B of Hole 504B. The estimates of apparent total porosity (on the basis of Archie's law) and fracture porosity (grey shading) are derived from the two laterolog measurements and their comparison, respectively (Pezard and Anderson, 1989, 1990). The massive flows are outlined with a black shading. A series of thin flows, of increasing porosity, decreasing thickness and resistivity with increasing time (decreasing age and/or depth) is outlined from 4145 to 4075 mbdf. The depth is given in meters below drill floor.

lithologic and hydrological consequences of this morpho-tectonic accretion model are introduced and discussed.

\section{The Concept of Mid-Ocean Ridges}

The discovery of MOR structures can be taken as far back as 1872 with the world-roving expedition of the H.M.S. Challenger and the acquisition of bathymetric data unveiling the presence of the Mid-Atlantic Ridge. However, the study of MORs as we view them today was initiated about 30 years ago in the wake of the plate-tectonics revolution with Menard (1960, 1967), Hess (1959, 1965), Heezen (1960), and Heezen and Ewing (1963), in particular. With the acceptance of plate tectonics as a unifying model, Menard (1967) was the first to relate spreading-rate and axial morphology in a model where the large-scale rugosity (that of 10 's of $\mathrm{kms}$ ) of the seafloor topography decreased with increasing spreading velocity (Macdonald, 1982; Gente, 1987). Nowadays, such observations are still valid and remain the best two-dimensional geophysical image to compare MORs accreted at different spreading rates. Since Menard (1967), the understanding of MOR processes have evolved with the publication of numerous models that may be classified in two main categories synthetized in Gente (1987): 
either static models where the MOR is described as accreted under near-steady-state conditions, or cyclic models where the emplacement is viewed as episodic.

\section{STATIC MODELS}

The static models tend to analyze MOR structures at a time-scale greater than one $\mathrm{Ma}$, and consequently consider the ridge as a constant structure in equilibrium with the underlying mantle. Such an approach was justified by isolated observations such as the fact that the zone of axial rifting was observed to coincide with the steady-state depression for slowspreading ridges (Atwater and Mudie, 1968, 1973; Deffeyes, 1970; Macdonald, 1982). As a consequence, all static models consider that the oceanic basement is created within a narrow interval located at the axis. The crust is generally accepted as being accreted under an extensional regime (Harrison, 1968; Deffeyes, 1970; Anderson and Noltimier, 1973), then tectonically reorganized as it moves up on the flanks of the edifice with eventual reversal of fault dips, rotation of fault blocks, and progressive decrease of block-offset with time (van Andel and Bowin, 1968; Harrison, 1974; Needham and Francheteau, 1974; Harrison and Stieljes, 1977; Macdonald and Atwater, 1978; Davis and Lister, 1977; Laughton and Searle, 1979).

The physical mechanisms used to explain accretion processes and the presence of an axial valley range from hydraulic head-loss due to viscous drag of asthenospheric material (Cann, 1968, 1974; Sleep, 1969; Lachenbruch, 1973, 1976; Sleep and Rosendahl, 1979; Colette et al., 1980; Searle, 1984), to extension and necking of the young lithosphere due to its thermo-elastic properties (Palmasson, 1973; Daignieres et al., 1975; Tapponnier and Francheteau, 1978; Emerman and Turcotte, 1984), or intrusion of mantle material within the crust leading to instabilities in the stress or gravity field (Piper and Gibson, 1972; Koide and Bhatacharji, 1975; Rea, 1975; Crane, 1978; Nelson, 1981).

\section{EPISODIC MODELS}

These models are in general more recent and more complex than static models. Having evolved in most cases from detailed analyses of MOR structures, either from submersible or from small-scale imaging of the seafloor with remote cameras and acoustic devices, they attempt to take into account the complexity of the axial morphology. In particular, the presence of fresh volcanic edifices often contrasted with the presence of intensively tectonized regions (Normark, 1976; Macdonald and Luyendyk, 1977; CYAMEX, 1981; Ballard et al., 1981; Choukroune et al., 1984; Whitmarsh and Laughton, 1976), leading to along-strike changes in morphology, and to the conclusion that volcanism on-axis might be episodic (Klitgord and Mudie, 1974; Lewis, 1979; Robinson et al., 1973; Gente et al., 1986; Kappel and Ryan, 1986; Gente, 1987; Macdonald and Fox, 1988). Considering that the influence of tectonic stresses is continuous through time on axis at macroscopic time-scale, the notion of volcano-tectonic cycles was introduced to describe accretion processes. Such cycles are composed of two distinct periods associated with the presence or absence of volcanic activity.

The volcanic period is a time of rapid construction within the axial valley, in a region often referred to as the 'neovolcanic zone' (NVZ) (Normark, 1976; CYAMEX, 1981; Ballard et al., 1981; Kappel and Ryan, 1986). At medium spreading-rate, that is 5.0 to $9.0 \mathrm{~cm} \mathrm{yr}^{-1}$ (full rate), this region of active volcanism is observed as relatively narrow and well localized on-axis ( 0.6 to $1.2 \mathrm{~km}$-wide at full rate). Such a restricted extrusion zone is elsewhere constrained by the existence of a clear record of inversions of the magnetic field in the direction of spreading (Vine and Matthews, 1963), with relatively narrow regions of reversal between positively and negatively magnetized intervals (Macdonald et al., 1983).

A wider zone ( 1.0 to $2.0 \mathrm{~km}$-wide at MSR), where volcanism is absent, is found occupied by older lava cut by numerous fissures. This zone constitutes the inner part of an even larger region often described as the 'tectonic zone' where active faulting is observed, with occasional tilting of crustal blocks resulting in a horst-and-graben morphology at $\mathrm{km}$-scale (Lonsdale, 1977; CYAMEX, 1981; Choukroune et al., 1984; Rangin and Francheteau, 1981; Ballard et al., 1981; Edwards, 1991).

Such observations resulted in the establishment of episodic accretion models with a changing axial morphology with time, in relation to volcanism. Lewis (1979) was one of the first authors to argue for volcanic periodicity to explain morphological 


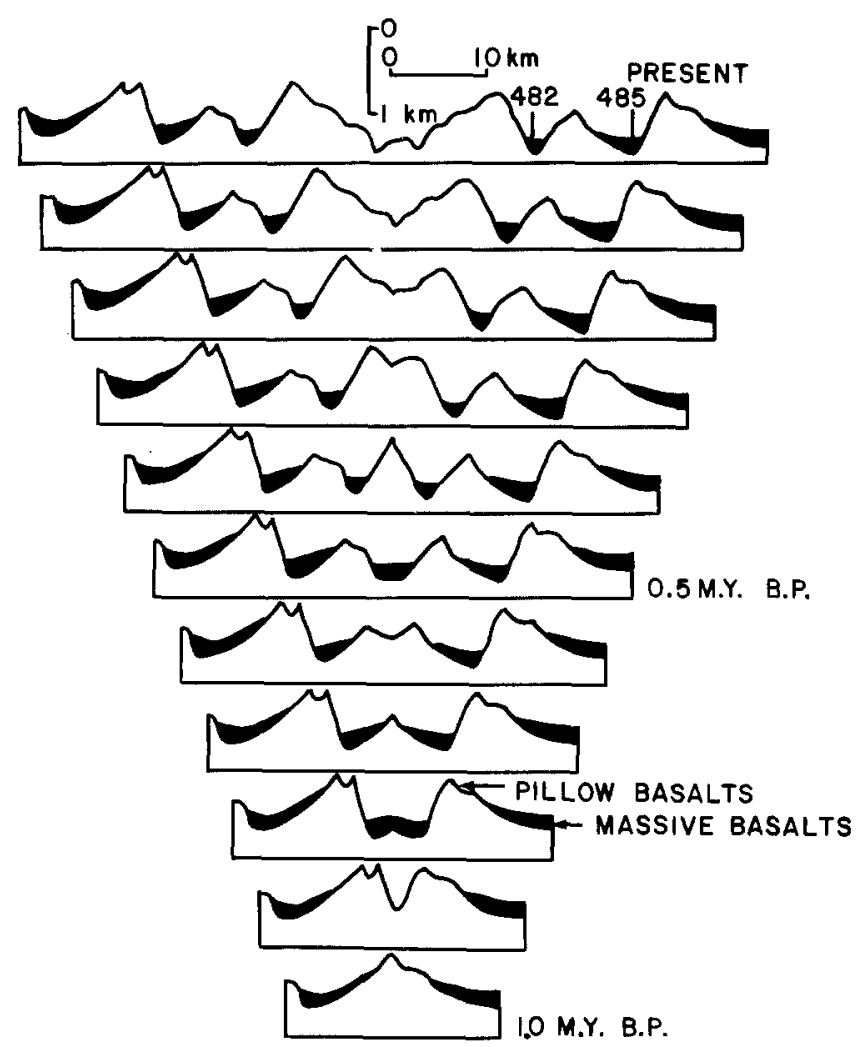

Fig. 5. Bathymetric reconstruction of the evolution of the EPR at $23^{\circ} \mathrm{N}$ of Lewis (1979). The deposition of sediments is included in the model, and topographic variations are associated with the discontinuous voleanic activity.

differences north and south of the Tamayo Fracture Zone, at $23^{\circ} \mathrm{N}$ on the EPR (Figure 5). In Lewis' model, the crustal morphology is defined on axis, then transported away on the flanks of the MOR structure. Kappel and Ryan (1986) presented a model (Figure 6) by which an elongated summit depression (ESD) develops to split the axial topographic high after the end of the volcanic phase. This collapse consequently equates to a period of volcanic quiescence at the axis (Gente et al., 1986). With Macdonald and Fox (1988), the presence of an ESD is related to that of a magma chamber, thereby implying that axial collapse (time T3 of Figure 6) might develop as a precursor of the next volcanic phase.

In the last two cases, the down-dropped floor of the ESD is characterized by hummocky, draped and fissured terrains also observed on the flanks of the crestal ridge and associated with the last phase of the volcanic episode (time T2). Spreading and conse-
TI

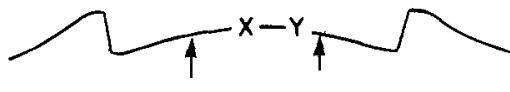

T2

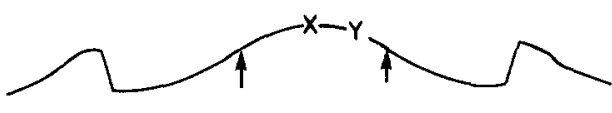

T3

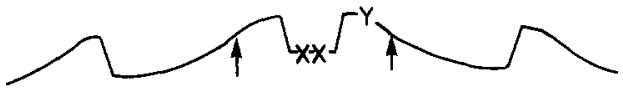

T4

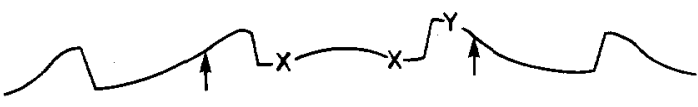

Fig. 6. Morphotectonic accretion model of Kappel and Ryan (1986). A crestal ridge grows from $T 1$ to $T 2$, then the ESD collapses into the crestal ridge during $\mathrm{T} 3$, followed by a growth of a new crestal ridge in the middle of the ESD (period T4). The axial structure is allowed to vary in width with time.

quent stretching of the axial structure then occurs with little volcanism (time T3), with an increasing number of fissures being observed during a period of extension of the young crust (time T4). As the next volcanic phase is initiated, the floor of the ESD is flooded by a series of massive flows, on top of which a new volcanic construction develops (times T1 through T2). The description of Macdonald and Fox (1988) equates to eliminating $\mathrm{T} 4$, eventually due to a faster spreadingrate in the region from which the model originates, as opposed to that of Kappel and Ryan (1986). A model similar to the latter was developed by Gente (1987) for MORs of varying spreading rates. Nested self-similar constructions are proposed to develop near the spreading axis to explain the observed axial topography, with the predominance of volcanism over tectonism at fast spreading-rates, and the opposite at slow spreading-rates (Figure 7).

In the following, a series of geological and geophysical observations of morphotectonic, volcanic and hydrological nature for medium spreadingrate MOR are presented in order to document the variety of structures and phenomena observed on- or near-the-axis. In the second part of the paper, these observations are used as a reference to understand how such structures might be observed in the vertical cross-section encountered in the borehole.

\section{Medium Spreading-Rate Mid-Ocean Ridges}

The axial part of medium spreading-rate MOR is generally constituted of a volcanic ridge 300 to 


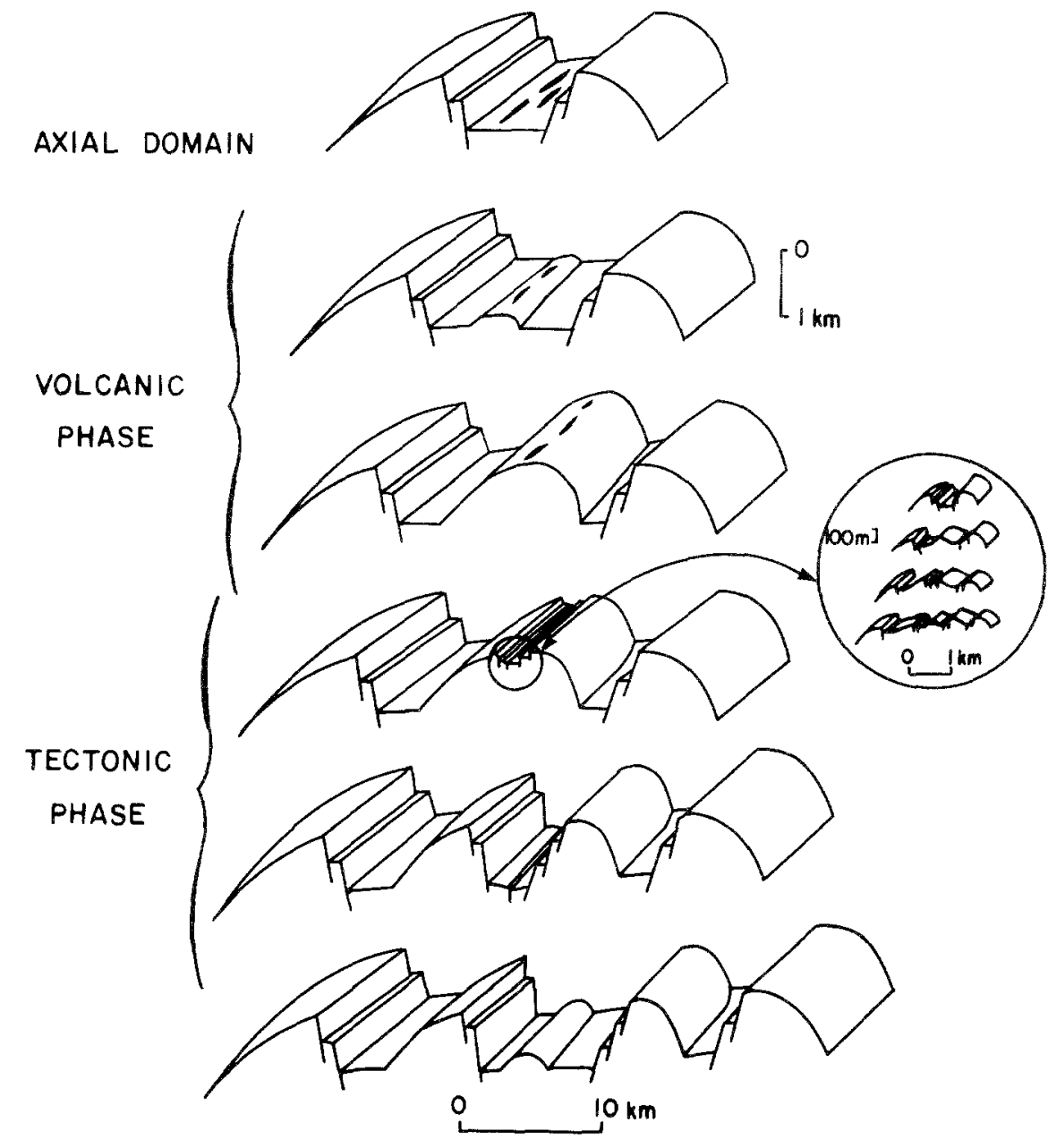

Fig. 7. Morphotectonic accretion model of Gente (1987) proposed for a wide spectrum of spreading-rates (from slow to fast). The temporal structure of the volcano-tectonic cycle defines the axial morphology (with the predominance of either volcanic or tectonic phases depending on spreading rate), via the development of nested elementary processes.

$800 \mathrm{~m}$-high and up to $10 \mathrm{~km}$-wide. This ridge is often cut by a 50 to 100 m-deep and 200 to 1500 m-wide graben (or ESD). Similar structures of smaller amplitude are found to define near-axis structures, with a narrow graben sometimes only as deep as a few meters. The volcanic and hydrothermal activity is in most cases limited to a 50 to $200 \mathrm{~m}$-wide interval located on axis (Macdonald, 1982; Choukroune et al., 1984; Gente et al., 1986; Kappel and Ryan, 1986; Gente, 1987; Macdonald and Fox, 1988). Where the ESD is narrow and has a constant width, it has a nearly constant depth and is often flooded by volcanic flows postdating those observed on the rim of the crestal ridge. Where the ESD is wide enough to contain isolated or continuous crestal ridges, the floor is extensively fissured and faulted, with flows originating from these fissures.

These morphotectonic observations might be synthetized by the models of Kappel and Ryan (1986) and Gente (1987) (Figures 6 and 7), or that of Macdonald and Fox (1988). It is therefore speculated that an axial volcanic high is built within an already stretched ESD by successive layers of fissure eruptions, during a period of excessive extrusive axial volcanism. When (1) the supply of magma is not sufficient to maintain a crestal-high on axis (Kappel and Ryan, 1986; Gente, 1987), or (2) prior to the development of a magma chamber (Macdonald and Fox, 1988), the collapse of the summit results in the development of a new ESD. This 
collapse may be very rapid. At this time, the textural similarity between flows on the new ESD-floor and on the rim, both created by the same eruptive event prior to the collapse, argues in favor of such morphotectonic models (Figures 6 and 7). However, the ephemeral existence of at least a minor depression which fills up from time to time, so that lava flows freely spill out over the crest and down the flanks, cannot be constrained from seafloor observations.

The periods of volcanic construction appear thus to follow two dominant eruptive mechanisms. Large volumes of fluid, hot and water-poor lava (Gente, 1987; Bonatti and Harrison, 1988) are often erupted rapidly on-axis in grabens to construct lava plains at a large scale, and ponds at a smaller scale. More viscous lavas equate to a slower eruptive regime and provide the material necessary to build crestal ridges, sometimes further from the axis than the former, during the second part of the volcanic period (time $\mathrm{T} 2$ on Figure 6). The residence time of such melts within a crustal reservoir, either locally in a magma chamber or due to transport along the ridge axis, may be assumed to be longer than that of more fluid melt that constitutes the first part of the volcanic sequence. In the following, it will be shown how vertical experiments conducted in boreholes provide additional information to test the models described above.

\section{Downhole Measurements}

Downhole measurements of rock physical and chemical properties provide a unique means to obtain a continuous and direct description of crustal structures. Among them, porosity and permeability are essential properties to describe the structure of the ocean crust, to understand the circulation of hydrothermal fluids, their interactions with the basaltic crust and, ultimately, the global chemical budget of oceanic plates. However, continuous in situ measurements of porosity and permeability in basalt are not at present directly obtained with geophysical logs.

\section{POROSITY AND PERMEABILITY}

Whereas porosity is estimated routinely from resistivity (Archie, 1942), nuclear (Ellis, 1987), or acoustic experiments in sedimentary formations (Wyllie et $a l ., 1958)$, the very different structure of the pore space of crystalline rocks, or the presence as traces of elements such as gadolinium or boron (with large capture cross-sections to neutrons), has prevented to date the development of an accurate method for deriving in situ porosity estimates. Since permeability is not only governed by porosity but also size, shape, tortuosity, arrangement of the pore space (all difficult to evaluate), and other parameters such as pore pressure or ambient stresses, no accurate derivation of permeability has been obtained uniquely from geophysical logs.

In the course of ocean drilling, Anderson and Zoback (1982), Anderson et al., (1985c) and Becker et al., (1989) have shown that in situ measurements of permeability made with a packer are suitable to study the variations with depth, and the modifications with age of this filtering system. In Hole 504B, the direct permeability measurements were compared with apparent porosity profiles derived from measurements of electrical resistivity (Becker, 1985), (1) confirming the vertical zonation of the lithostratigraphy of the oceanic crust known from ophiolite studies (Gass and Smewing, 1973; Kidd, 1977), (2) emphasizing the overall decrease in transmissive properties of the crust with increasing depth, and also (3) pointing out the limitations of the resistivityporosity-permeability transform in sections thought to be porous (with apparent porosity values up to $7.0 \%$ at the base of Layer $2 \mathrm{~B}$ ), but measured to be poorly permeable (of the order of $10^{-17} \mathrm{~m}^{2}$ about $0.01 \mathrm{mD}$; Becker et al., 1989).

\section{ELECTRICAL PROPERTIES OF MORB}

In situ measurements of electrical resistivity respond directly to conductivity changes in the rock surrounding the borehole. The presence of vesicular pores, cracks and microcracks, either fluid-filled, or plugged with precipitated conductive alteration minerals such as chlorites, zeolites, and smectites create a path for current flow. Pezard (1990) reports a series of core measurements aimed at evaluating whether alteration minerals contribute in a significant amount to current conduction during resistivity logging at 504B. If present, such contribution would cause estimates of porosity through Archie's law to be too high. The results are used to analyze the data recorded in situ, then discussed in relation to the porosity-permeability anomaly described earlier. In situ, the electrical conduction appears to be a combination of electrolytic mechanisms for 
fluid-filled fractures, and surface-mediated ion transport for conductive alteration minerals. Since an order of magnitude separates the resistivity of alteration minerals (a few $\Omega \mathrm{m}$ in situ), to that of seawater (about $0.2 \Omega \mathrm{m}$ at $25^{\circ} \mathrm{C}$ ), the measurements of electrical resistivity are sensitive to the progressive sealing of the oceanic crust with basalt alteration products.

\section{DSDP Hole 504B}

On Leg 111 of the ODP, the Joides Resolution returned to DSDP Site 504, in the eastern equatorial Pacific (Figure 1). Hole 504B was re-entered to study the crustal structure and the hydrothermal processes at this well-sedimented reference site (Becker et al., 1989). Leg 111 also provided the opportunity to conduct an extensive suite of in situ experiments, including permeability measurements in the sheeted dikes complex and the recording of continuous electrical resistivity data with the Schlumberger Dual Laterolog tool (DLL). An apparent porosity profile was computed from Archie's formula (1942), then compared to in situ permeability measurements. This comparison led to the low permeability-high apparent porosity paradox described earlier by Becker (1985), as it seemed contradictory that low apparent porosity dikes from Layer $2 \mathrm{C}$ (below $1.0 \%$ ) and high apparent porosity pillows from Layer $2 \mathrm{~B}$ (above $7.0 \%$ ) have the same permeability.

\section{In situ RESISTIVITY MEASUREMENTS}

The principle of the DLL is to measure the intensity of a variable current focussed in a $60 \mathrm{~cm}$-thick cylindrical beam, and flowing from a downhole electrode to a remote return under a fixed difference of potential (Ellis, 1987; Pezard, 1990). The intensity of the measured current is inversely proportional to the formation resistivity. This sensor is accurate at high resistivity values (error under $1.0 \%$ up to $40,000 \Omega \mathrm{m}$ ), and provides two measurements of resistivity (referred to as 'deep' for LLd and 'shallow' for LLs) due to their respective horizontal penetration into the rock. On Leg 111 of ODP, the measurements made with the DLL covered depths from $5003 \mathrm{~m}$ to $3758 \mathrm{~m}$ (or $1529 \mathrm{mbsf}$ to $284 \mathrm{mbsf}$ ), with a datum acquired every $15.2 \mathrm{~cm}$. An increase of about two orders of magnitude in resistivity values is observed from the highly porous and altered Layers $2 \mathrm{~A}$ and $2 \mathrm{~B}$ where the average value in the pillows is about $10.0 \Omega \mathrm{m}$, to the sheeted dikes of Layer $2 \mathrm{C}$ where the average value is about $250.0 \Omega \mathrm{m}$ (Figure 8).

These measurements are favorably compared to those of Becker (1985), and to forward models of electromagnetic measurements made near the East Pacific Rise (Cox, 1971; Young and Cox, 1981; Cox et al., 1986). The latter were best modeled with a $1.5 \mathrm{~km}$-thick upper layer of high conductivity $\left(0.1 \mathrm{~S} \mathrm{~m}^{-1}, 10.0 \Omega \mathrm{m}\right)$ and, underneath, a region with lower conductivity values $(0.04 \mathrm{~S} / \mathrm{m}, 250.0 \Omega \mathrm{m})$ that may extend downward to about 6.0 or $7.0 \mathrm{~km}$. The porosity and permeability profiles (Figure 9) derived from the combined analysis of downhole and core measurements indicate (1) that surface conduction associated with the presence of alteration minerals cannot be ignored, (2) that good agreement is obtained with permeability measurements obtained from packer experiments after correction for surface conduction (Pezard, 1990), and (3) that the only interval with porosity values on the order of $10 \%$ is located in the uppermost part of the basement, which defines seismic Layer $2 \mathrm{~A}$.

\section{HYdROLOGY AND MORB ALTERATION}

A series of constraints on the accretion, structure, and hydrology of the upper crust is derived from analyses of laboratory measurements, in situ geophysical and geochemical experiments, and atteration parageneses determined by mineralogical and chemical analyses. The structure of each seismicallyand hydrologically-defined section of the upper oceanic crust is discussed in the context of past and present hydrological regimes. The boundaries between the three mineralogical and chemical alteration zones (Honnorez et al., 1983; Emmermann, 1985; Alt et al., 1985, 1986a, 1986b; Laverne, 1987) are included in Figures 8 and 9. The upper-pillow alteration zone (UPAZ) is characterized by reactions of basalt with seawater occuring at high water-rock ratios and low temperature (below $60^{\circ} \mathrm{C}$ ), with the occurrence of iron-hydroxides, celadonite-nontronite, and saponite ( $\mathrm{Mg}$-smectite) as a replacement for olivine throughout the rock. The lower-pillow section (LPAZ) is characterized by reactions at lower waterrock ratios, higher temperatures $\left(60\right.$ to $110^{\circ} \mathrm{C}$ ), and by the dominant presence of saponite and pyrite as alteration products. This boundary is abruptly out- 


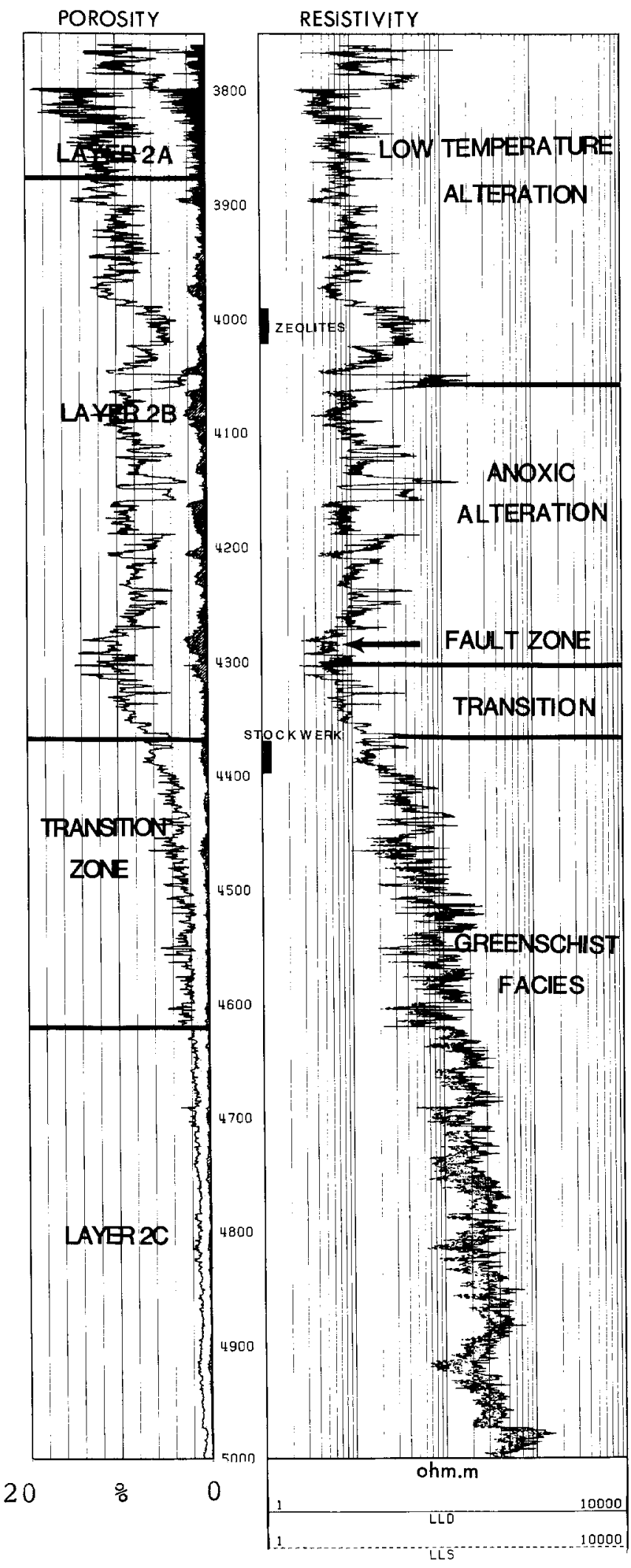

lined by the geochemical log (Pezard and Anderson, 1989), and this strong mineralogical zonation suggests the presence of a permeability barrier between these two alteration zones. This barrier appears on the computed-permeability profiles (Figure 9 ) as a 15-meter-thick low-permeability section (a few microDarcy in average) that equates to lithostratigraphic Unit 27 described from cores as a massive flow (Cann et al., 1983; Figure 10).

This massive flow is therefore the barrier between two distinct hydrological regimes crossed by and identified in the drillhole. The abrupt transition from oxidative seawater alteration (UPAZ), to a reducing environment (LPAZ) calls for a permeability barrier of significant lateral extent. In a similar way, the transition from reducing, low-temperature alteration facies (Figure 6; LPAZ) to greenschist facies (GFAZ) is located at $4372 \mathrm{~m}$ (898 mbsf; Emmermann, 1985; Alt et al., 1985, 1986a, 1986b; Laverne, 1987), where a pair of low-porosity units of intrusive origin is located (DSDP Units 57 and 61). These two units appear to cap the stockwork-like section discovered during Leg 83 of DSDP (Anderson, Honnorez, Becker et al., 1985a), which emphasizes the strong lithostratigraphic control on hydrothermal alteration. The mineralized zone developed within Unit 63 (the lowermost pillow unit of significant thickness recognized in Hole 504B) as the result of mixing with and quenching by seawater circulating above and hot $\left(350{ }^{\circ} \mathrm{C}\right)$ hydrothermal fluids ascending from the dike-section (Honnorez et al., 1983). The zone of transition in alteration facies located above this boundary (Figure 8) appears thus to have developed between this now-sealed precipitation interval and an inferred fault-zone located at $4300 \mathrm{mbdf}$, as upwelling hot fluids flowed into the permeable fault zone, hence preventing them from permeating the hanging wall of the fault. The discussion below is guided by this mineralogical zonation.

Fig. 8. Electrical resistivity measurements in Hole 504B, and related shipboard analysis of apparent porosity on the basis of Archie's law (1942). An estimate of fracture porosity (grey shading) is derived from the comparison of the two laterolog measurements (Pezard and Anderson, 1990). The different seismic Layers are indicated in the porosity track, and the alteration zones, derived from chemical and mineralogical analyses, in the resistivity track (Alt et al., 1986a, 1986b; Laverne, 1987). The depth is given in meters below drill floor. 


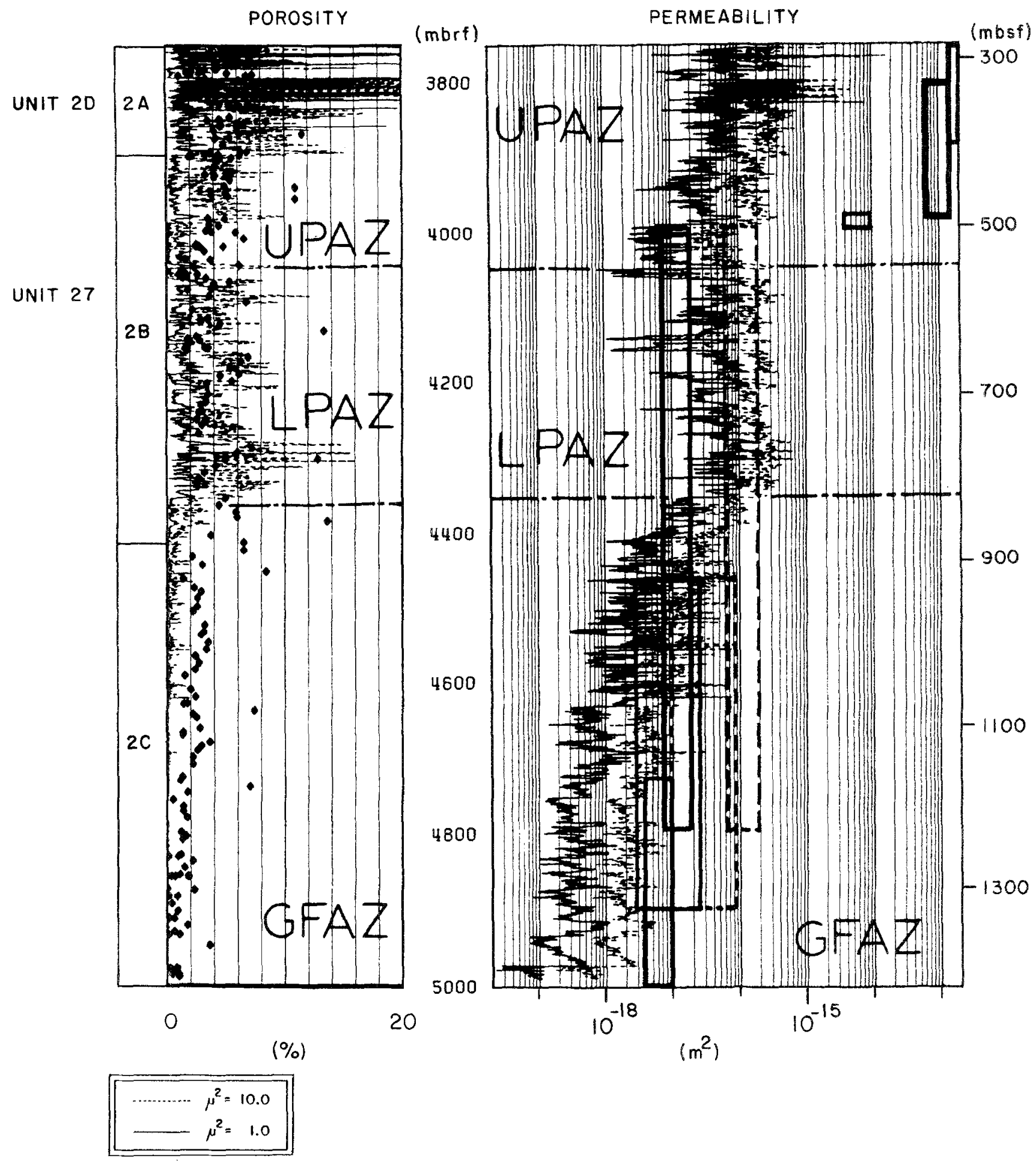

Fig. 9. Clay-corrected free-water porosity profiles computed from two different models of pore-surface geometry (with $\mu 2=10.0$, and $\mu 2=1.0$ ). The square diamonds represent porosity measurements made on cores. Alteration zonation (UPAZ, LPAZ and GFAZ). Computed permeability profiles obtained with $\mu 2=10.0$, and $\mu 2=1.0$, and plotted in $\mathrm{mD}$. The bulk permeabilities measured in situ are represented with elongate vertical rectangles. The vertical extent of the rectangle represents the depth interval over which average permeabilities were measured. The horizontal extend of the rectangles represents the range of estimated errors in the permeability determination (after Becker et al., 1989). The two dashed rectangles indicate new estimates of permeability from in situ packer experiments computed with revised parameters (Becker et al., 1989). Alteration zonation (upper pillow 'UPAZ', lower pillow 'LPAZ' and greenschist facies 'GFAZ' alteration zones) are indicated after Alt et al., (1986a) and Laverne (1987). 


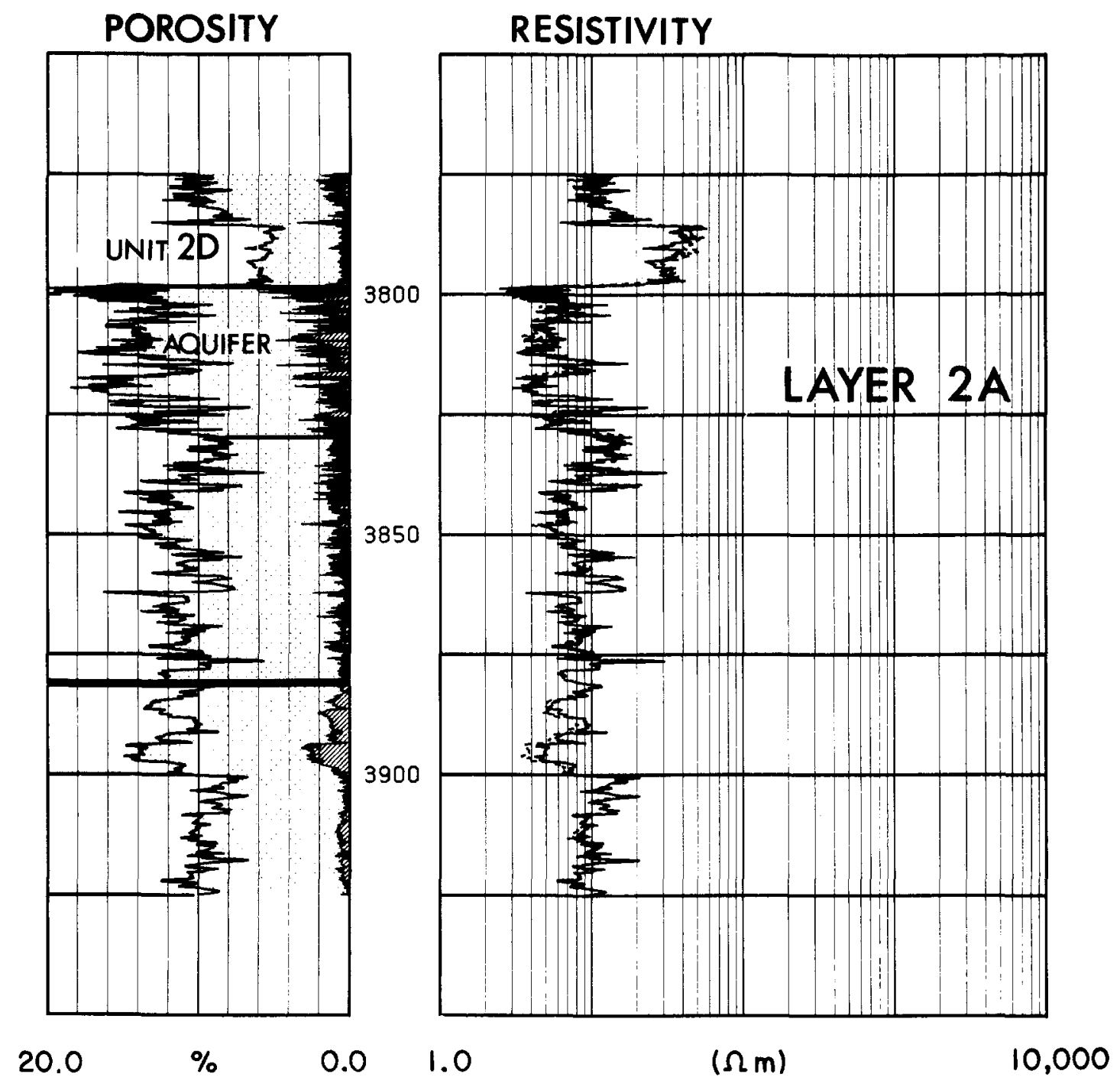

Fig. 10. Electrical resistivity measurements recorded in Layer 2A of Hole 504B. The estimates of apparent total porosity (on the basis of Archie's law) and fracture porosity (grey shading) are derived from the two laterolog measurements (Pezard and Anderson, 1989, 1990). The presence of horizontal and vertical fractures is inferred within Layer $2 \mathrm{~A}$, whereas vertical fractures dominate below. The high fracture porosity computed at $3895 \mathrm{~m}$ could be due to the presence of a fault zone. The depth is given in meters below drill floor.

The subhorizontal nature of the fault inferred from seismic, magnetic and electrical experiments (Becker et al., 1989) is outlined in DLL data by a short interval near $4300 \mathrm{mbrf}$ where LLs $\geqslant L L d$ (Pezard and Anderson, 1990). The Transition Zone from dikes to pillows is a region of continuously increasing electrical resistivity with increasing depth (Figure 8), supporting an increase in the density of dikes with increasing depth largely documented in ophiolite studies (Gass and Smewing, 1973; Kidd, 1977). The high-frequency character of the computed porosity profile in this zone (Figure 8 ) reflects alternating sequences of intrusive (more massive) and extrusive (more porous) units. In addition, the computed porosity decreases with depth over this interval to become as low as a fraction of a percent at the top of Layer $2 \mathrm{C}$, and remains low to the bottom of the hole (Figures 8 and 9).

\section{CRUSTAL MORPHOLOGY AND SEISMIC STRUCTURE}

\section{Layer $2 A$}

Layer $2 \mathrm{~A}$ is characterized by the highest porosity values computed in Hole 504B (Figure 10). These high porosity values are related to the presence of horizontal fractures (Newmark et al., 1985; Pezard and Anderson, 1989, 1990) down to $3880 \mathrm{~m}$ 
(406 mbsf), below which a regime of mainly vertical fractures is observed. The presence of this boundary fits with previous definitions of the limit between Layer 2A and Layer 2B in Hole 504B (CRRUST, 1982; Anderson et al., 1985b; Newmark et al., 1985), and the original concept of a fractured, low-velocity Layer 2A (Houtz and Ewing, 1976; Francheteau, 1983). No definite explanation has been given so far for the existence of a 'seismically slow' Layer $2 \mathrm{~A}$, as opposed to an acoustically faster Layer $2 \mathrm{~B}$. It has sometimes been related to a zone of intense alteration of the crust (Donelly, Francheteau et al., 1979; Salisbury et al., 1980). Such a velocity decrease (to values of 2.0 to $3.0 \mathrm{~km} \mathrm{~s}^{-1}$ ) has been noticed for a zone about $100 \mathrm{~m}$ thick at the axis of the EPR (Vera, 1989), which implies that Layer $2 \mathrm{~A}$ is mainly of morphological origin. In Hole 504B, the upper 130 meters have the largest apparent porosities of the entire hole, with an average of $7.0 \%$ in the pillows (Figure 11). The section of most intense fracturing is $30 \mathrm{~m}$-thick and bounded on top by Unit 2D (from 3785 to $3799 \mathrm{~m} ; 311$ to $325 \mathrm{mbsf}$ ), a $14 \mathrm{~m}$-thick massive flow (Figure 11).

The set of temperature profiles recorded during the successive drilling legs in Hole 504B (Figure 12) shows that the bottom of Unit 2D defines the depth at which the temperature increases rapidly (during DSDP Leg 70 and 83), as the ocean water enters an under-pressured aquifer (Anderson and Zoback, 1982; Anderson et al., 1985c). This defines the upper limit of the main zone of water intake into the crust, although thinner permeable zones might be located above Unit 2D (Figure 9). The temperature gradient recorded during Leg 111 (Gable et al., 1989) suggests that the main interval of water inflow is $30-\mathrm{m}$ thick and located below unit $2 \mathrm{D}$, which equates to the section of highest computed-porosity and permeability in the hole (Figure 9). This relationship has several possible implications suggesting, for example, that the structure allowing the under-pressured aquifer to develop was created within the NVZ, where Unit 2D was emplaced. This under-pressured zone located in this high permeability conduit has been thought to have appeared during sealing of the upper part of the crust, in relation to the diagenesis of diatom oozes into chert (Hobart et al., 1985). Another explanation arises if hydrothermal waters already circulated through the crust were trapped at shallow depth below Unit $2 \mathrm{D}$ close the the ridge axis.
Similar borehole inflows have been encountered in other deep-sea drillholes such as DSDP Hole 332 (Hyndman et al., 1976), although never studied as extensively as at Hole 504B. A kilometer away from 504B, Hole 501 penetrated $73 \mathrm{~m}$ into the basement. Two massive flows, comparable in size to Unit $2 \mathrm{D}$ in Hole 504B, were drilled-through half-way into the hole (Figure 13). In situ temperature measurements indicated as well the presence of a downward waterflow in a zone located below massive units, in this case Unit 4 (Cann et al., 1983; Figure 14). In contrast, Hole 504A penetrated only a few meters into basement before being abandoned (Figure 13). The temperature profile does not show any seawater inflow into the upper crustal interval (Figure 15), and the presence of an underpressured aquifer appears consequently to be related to the presence of a massive unit (the aquitard) located on top of a highly porous interval. If such massive units are considered as the onset of a volcanic episode (as in Hole 501), or even the main outpouring of the early phase of a volcanic cycle, then the underlying porous pillows where the aquifer is observed to develop equate to the last phase of the previous volcanic sequence.

Along different MOR's, lava morphologies have been found to be dependent on temperature and viscosity at eruption, phenocryst content, and spreading-rate (Bonatti and Harrison, 1988), evolving from sheet-flows to pillow lava with time (Hyndman and Salisbury, 1983), as the volcanic construction develops and the crustal magma chamber weakens. The pillows erupted during the last phase of the volcanic episode would accordingly be those with the highest viscosity, the lowest temperature at emplacement, and correspond to the time T2 of Kappel and Ryan (1986; Figure 6), that of maturity of the volcanic edifice. Those pillows are thus excellent candidates to form the weak collapse-structures of Rangin and Francheteau (1983) and Hekinian (1984). After collapse of the ESD (time T3; Figure 6), further destruction of these mechanically-weak structures is implied, as well as the capping by a $10 \mathrm{~m}$-thick impermeable flow at the onset of the next volcanic phase. As we shall see in the following, the actual onset of the next volcanic sequence might be slightly different, with the extrusion of a few pillows prior to a massive extrusion. In both cases, this sequence of volcanic events provides the structure necessary to develop an aquifer in this zone of high and heterogeneous porosity. 

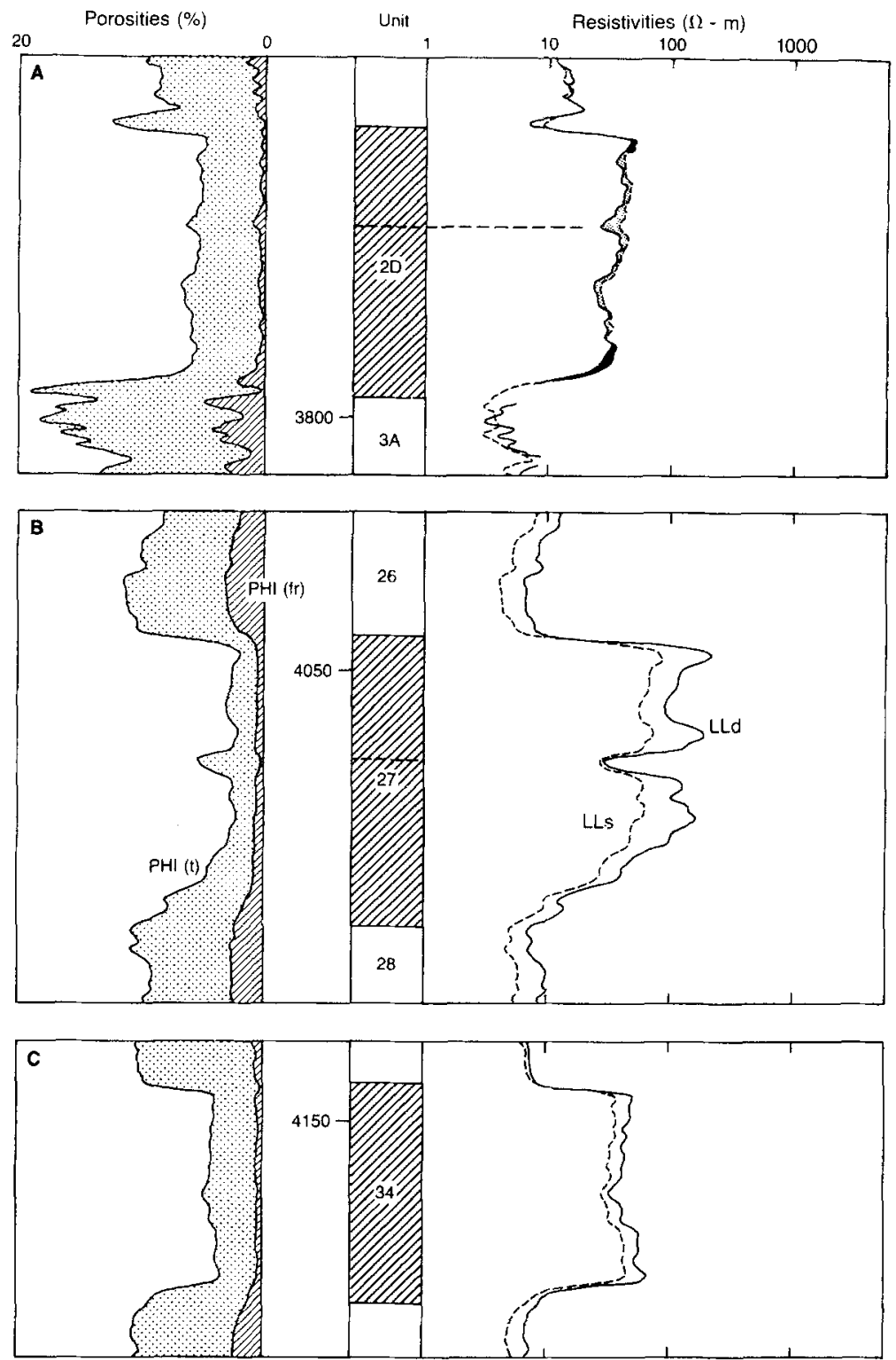

Fig. 11. Examples of resistivity patterns obtained for the massive units of seismic Layers $2 \mathrm{~A}$ and $2 \mathrm{~B}$ in Hole 504B. (A) Unit 2D, (B) Unit 27 and (C) Unit 34. The very symmetrical sigma-shape of Unit 34 is identified for the lower part of Unit $2 \mathrm{D}$, corresponding to the first of the two flows that constitute Unit 2D. The gradual transition from flow to pillow resistivity values observed at the base of Units 27 and

$2 \mathrm{D}$ could correspond to the extrusion of a massive unit on top of a rubbly surface. The depth is given in meters below drill floor.

Under active hydrothermal circulation, the presence of a 14-m-thick impermeable cap might be sufficient to allow the measured underpressure within the aquifer to develop (Williams et al., 1986), regardless of the presence of the impermeable chert-layer at the base of the sedimentary column (Hobart et al., 1985) elsewhere found to be laterally discontinuous (Becker et al., 1989).

\section{Layers $2 B$ and $2 C$}

The discriminative analysis of in situ resistivity data (Figure 8 ) outlines the dominant presence of vertical fractures from the top of Layer $2 \mathrm{~B}(3880 \mathrm{~m}$, or $405 \mathrm{mbsf}$ ) to the bottom of the drillhole. The low values of apparent porosities (computed with Archie's formula) in the massive units provide a means to discriminate the flows and sills from the 


\section{HOLE 504B}

\section{MEASURED EQUILIBRIUM TEMPERATURES}

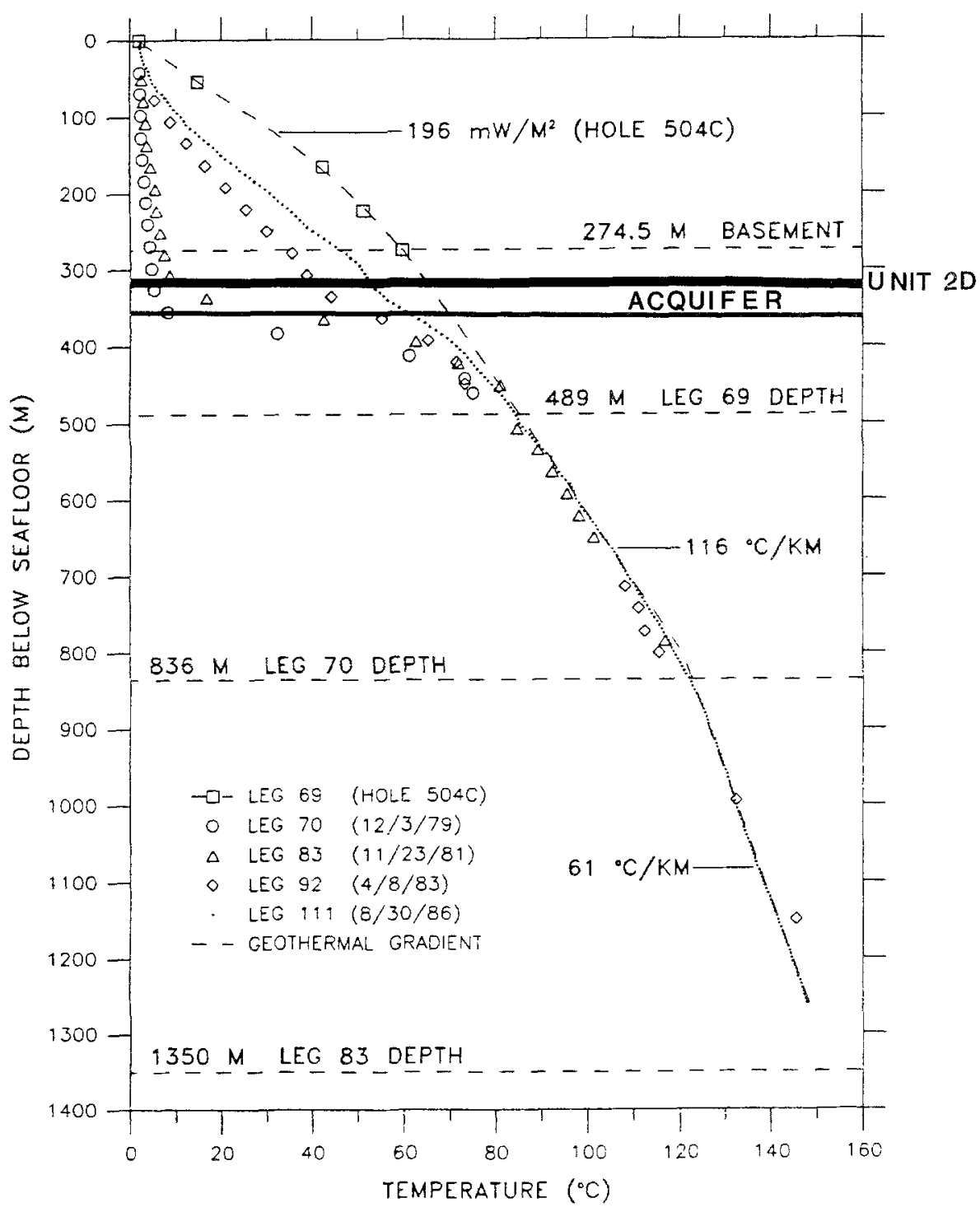

Fig. 12. Temperature logs recorded in Hole 504B during Leg 69, 70, 83, 92 and 111 (after Becker et al., 1989). The underpressured aquifer is observed to be confined below the massive flows of Unit 2D. The depth is given in meters below sea floor.

more porous pillow units (Figures 4 and 8 ). Fracturing in the flows is mainly restricted to the cooling edges, whereas the intensity of the fracturing within pillow units is of two possible origins: either (1) thermal due to stresses applied during quenching and cooling of an overlying massive unit (Figures 4 and 10 ), or (2) tectonic due to basement faulting ( $4300 \mathrm{~m}$; $826 \mathrm{mbsf}$; Figure 8 ). One of the thick flows, Unit
27 coincides with a major alteration boundary (Fig ures 8, 9 and 10), and has the lowest computed porosity (a fraction of a percent) and permeability (a few microDarcies) of the extrusive section. Below this boundary, the most intense parageneses (Figure 8) are confined to pillow sections located directly below massive units $(4160 \mathrm{~m}, 4330 \mathrm{~m}$, and $4380 \mathrm{~m}$; Pezard and Anderson, 1989). The high cation exchange 


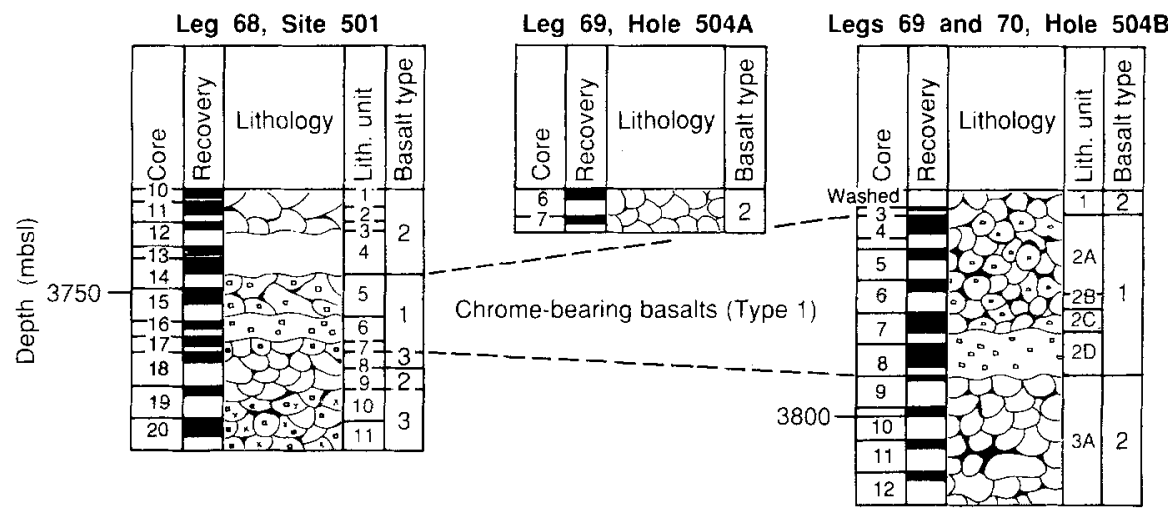

Fig. 13. Compared lithologies in Hole 501, 504A and 504B. At Site 501, the Type 1 massive unit (Unit 6) is observed to be thinner and shallower within the crust than Unit $2 \mathrm{D}$ is, at Site 504 . If these two units are considered as emplaced as a consequence of the same eruptive event, both unit thickness and depth of burial within basement point at a magma source located closer to Site 504 than to 501 . The depths are given in meters below drill floor.
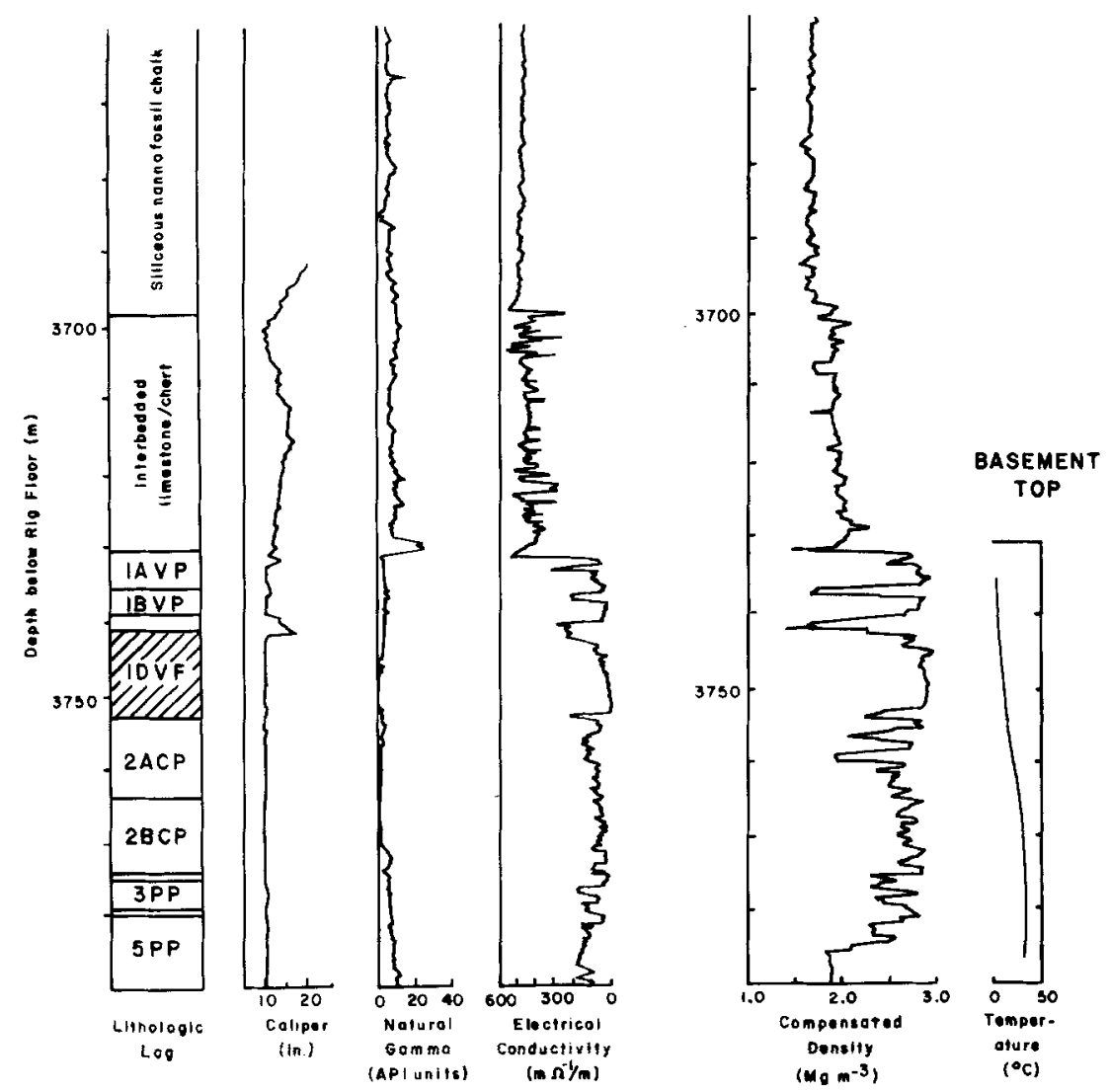

Fig. 14. Downhole measurements in Hole 501. Above Unit 6 (here refered as 1DVF), the upper basement is mostly constituted with pillows and thin flows. The temperature data show, as in Hole 504B, a fluid-flow from the sea floor into the basement, with an inflection point located below the massive unit (Unit 6) pointing also at the presence of an underpressured region below it. The depth is given in meters below drill floor. 

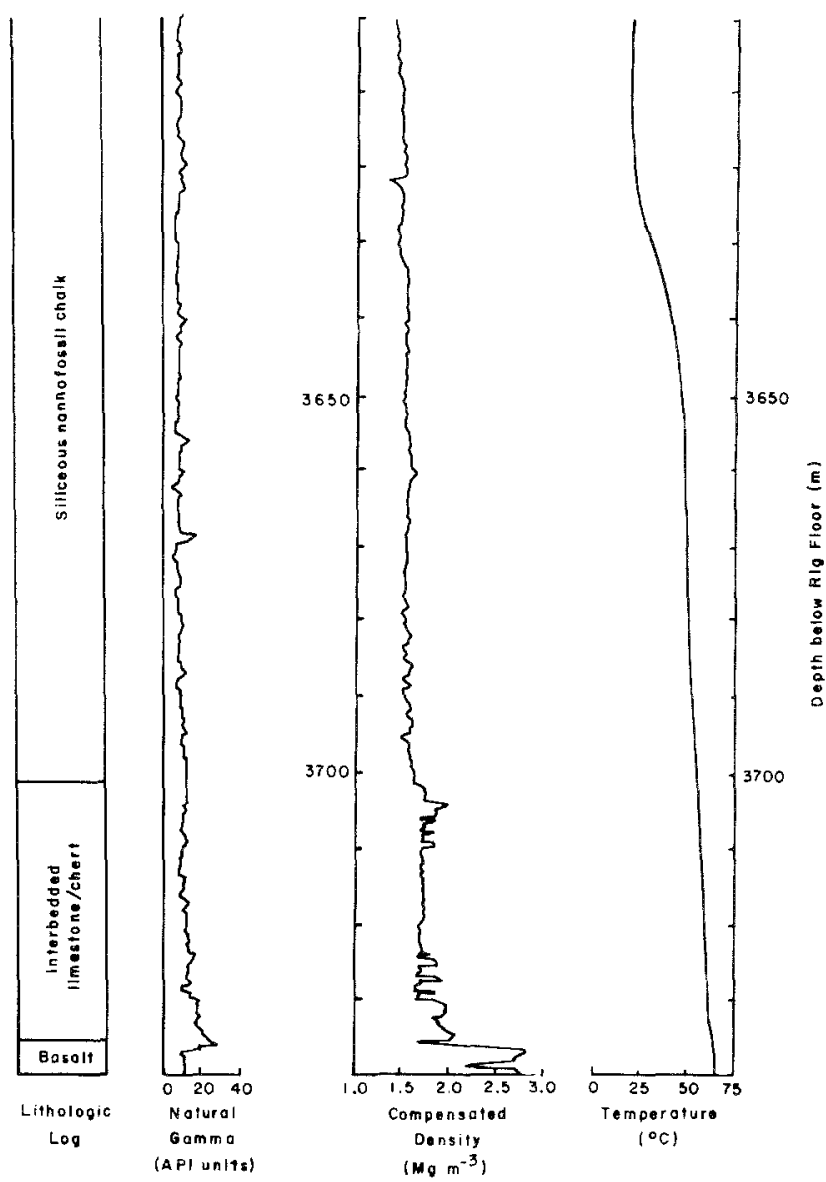

Fig. 15. Downhole measurements in Hole 504A. Only a few meters of basalt were penetrated and the temperature data do not show any fluid-inflow within basement (the inflection point is here located within the sedimentary column). The depth is given in meters below drill floor.

capacity (CEC) measured in these low-porosity units indicates that the entire crust has been permeated and altered by hydrothermal fluids.

Below Unit 27, Unit 28 corresponds to the only interval outside Layer $2 \mathrm{~A}$ where intense subhorizontal fracturing was observed on the BHTV images (Newmark et al., 1985). It might thus be compared to Unit 3A (also made of pillows, located below a massive flow, and showing subhorizontal conductive structures; Figure 10), even though this interval is now sealed, as indicated by the high shear velocities recorded over this interval (Moos et al., 1990) with respect to that obtained elsewhere in Layer $2 \mathrm{~A}$. Therefore, unit 28 could tentatively be considered as the locus of a paleo-aquifer sealed by a massive unit (Unit 27), originally comparable to that observed today in the upper part of the crust. This interval of initially high porosity and permeability was rapidly sealed near the ridge-axis, as indicated in alteration parageneses by low water-rock ratios, and is consequently observed today as poorly permeable.

On the basis of $\mathrm{Sr}$-isotopes and $\partial \mathrm{O}^{18}$ measurements, Barrett et al., (1983), Barrett and Friedrichsen (1983), Friedrichsen (1985) and Alt et al., (1986a, 1986b) discuss the existence of a paleo-seawater/basement interface at a depth of $900 \mathrm{mbsf}$ (within Unit 63, in the Transition Zone), at times of high-temperature water-rock interactions. The high $\mathrm{Sr}$-values measured in the lower interval are used to argue for a relatively long exposure (up to a thousand years) of this interface to ocean water, being later covered by additional magmatism with possible development of a seawater aquifer underneath. Such an interface, now located within the Transition Zone, can be considered as representing the upper part of the crust during early phases of seafloor volcanism. 


\section{MORB CHEMISTRY AND ACCRETION PROCESS}

The chemistry of the basalts recovered from Hole 504B is remarkably uniform in major oxide composition. They are mostly fine-to-medium grained, aphyric to highly phyric, and tholeiitic by nature (Hubberten et al., 1983; Emmermann, 1985). These basalts are relatively primitive, as indicated by high Mg-number $([\mathrm{Mg} /(\mathrm{Mg}+\mathrm{Fe})]=0.60$ to 0.70$)$, which suggests a small degree of crystal fractionation prior to emplacement and, in turn, a short residence time within what is inferred to be a periodically replenished magma chamber (Autio and Rhodes, 1983; Natland et al., 1983). In addition, most of the rocks sampled by Hole 504B are very primitive and depleted in $\mathrm{TiO} 2$, incompatible trace elements, characterized by high liquidus temperatures $\left(1230\right.$ to $\left.1260^{\circ} \mathrm{C}\right)$, and referred to as depleted or type-D basalt (Autio and Rhodes, 1983). Such a composition indicates that the asthenospheric magma source sampled at Site 504 might have undergone earlier melting events.

Only a few samples, all extruded as pillows (Units 5,36 , and 83), are more typical of MORB tholeiites (referred as type-M), in rich $\mathrm{TiO} 2$ and incompatible trace elements, with lower liquidus temperatures $\left(1210^{\circ} \mathrm{C}\right)$. The two types $(\mathrm{M}$ and $\mathrm{D})$ cannot be related by fractionation processes (Autio and Rhodes, 1983). Two distinct sources of magma are thus necessary to explain the sequence observed in Hole 504B. The large majority of type-D basalts argues for the proximity of Site 504 to this magma source at emplacement. Type-M basalts, extruded as pillow eruptions, would then correspond to a more distinct source during the accretion. Within the main group (type-D), the variety of non-comagmatic or derivative magma-types argues for extensive mixing in the absence of a large magma chamber (Autio and Rhodes, 1983), which is in agreement with the high Mg-numbers measured. Rather, a series of small, near steady-state magma chambers not small enough to solidify to great extent between eruptions, but periodically replenished from a very uniform mantle source is proposed by Autio and Rhodes (1983), and Natland et al., (1983). As group-D appears to form a single differentiation sequence, the cyclic nature of the magmatic process is shown in the stratigraphic column by repetition and changing order of the subgroups (D1 to D7). Nevertheless, a jump from D4 to D7 (from Unit 28 to Unit 27, for example) cannot solely be explained by fractionation processes (Autio and Rhodes, 1983). Segmentation in terms of time and/or space of the magma sources is thus necessary to interpret the contiguous presence of such basalts in vertical cross-section. Natland et al., (1983) confirm that sizeable changes in magma composition are required between subgroups, notably in the cases of Unit 28 and 27, or Unit 3A and 2D (D3 to D4 of Autio and Rhodes, 1983).

To summarize, the accretion process for the extrusive crust sampled at Site 504 might be modeled by the regular replenishment of a small, near steady-state magma chamber. Such a magmatic regime, with injection of 5 to $10 \%$ of the volume of the crustal chamber every 5000 years, for example, could be explained by the model of Usselmann and Hodge (1978).

\section{Accretion Model at Intermediate Spreading-Rate}

With the constraints defined from seafloor observations, and on the basis of the widely accepted episodic models of Lewis (1979), Kappel and Ryan (1986) and Gente (1987), new insights are gained about accretion processes, with the integration of results obtained in the upper part of Hole 504B. The implications of downhole observations are discussed here within the framework of simple structures that now need to be introduced to describe the evolution in time and space of the MOR edifice.

\section{CONSTRAINTS ON THE MODEL}

The crustal section sampled at Site 504 was accreted at medium spreading-rate $\left(7.0 \mathrm{~cm} \mathrm{yr}^{-1}\right.$ at full rate), that is with mechanisms comparable to those described by Kappel and Ryan (1986), Gente (1987) and others. The morpho-tectonic sequences of accretion at such a spreading-rate might be contrasted with that observed along slow-spreading ridges where long intermagmatic periods are observed, and fast-spreading ridges where the volcanic activity is believed to be more frequent (Figure 16). However, it is not known at this stage how long volcanic episodes and inter-volcanic periods might last at this intermediate rate of accretion.

A way to constrain and illustrate this accretion process in time and space consists in using the notion of 'neo-volcanic zone' (NVZ) in a statistical way, considering that the effusive part of the oceanic crust 


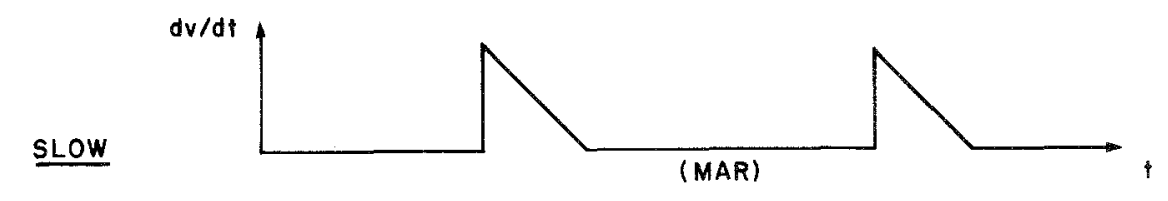

MEDIUM

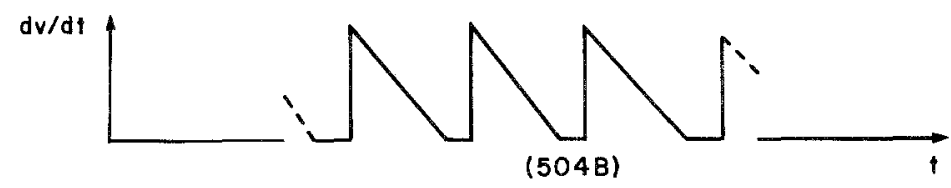

FAST

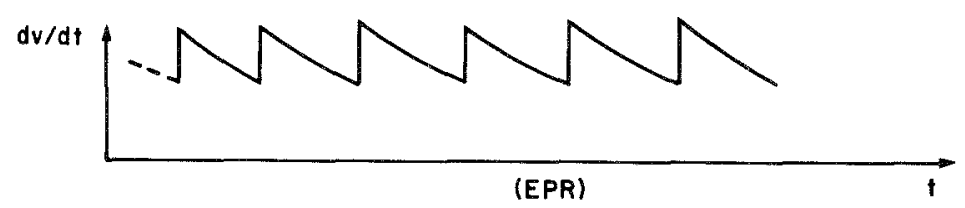

Fig. 16. Conceptual models for the different volumes of lava accreted per unit time at slow, intermediate, and fast spreading rates.

is entirely constructed within this conceptual interval. Even though the accretion process is known to be discontinuous in time and space, with ridge jumps and along-axis discontinuities for example, the NVZ might be viewed as an interval of distributed sources of active-volcanism for a particular accretion sequence. In this respect, a kilometer-wide zone seems to be a maximum at such a spreading-rate, both from magnetic constraints and seafloor observations of volcanic activity. To visualize easily the different processes active at or near the ridge-axis, it is convenient to use the simple coordinate system defined in
Figure 17. The $\mathrm{X}$-axis is chosen perpendicular to the spreading-axis and the $\mathrm{Z}$-axis represents the depth.

In Hole 504B, the volcanic section extruded on the seafloor might be considered as approximately $650-\mathrm{m}$ thick, if an arbitrary mid-point is chosen within the Transition Zone, as the base of Layer 2B. The base of the stockwork ( $4400 \mathrm{~m}$ or $925 \mathrm{mbsf}$ ) is used here, even though a different point within $+50 \mathrm{~m}$ could equally be picked to illustrate this model. Considering that this $650 \mathrm{~m}$-long interval is made of lavas emplaced on the seafloor as a layered cake (neglecting dikes and sills for now), the accretion process might be viewed

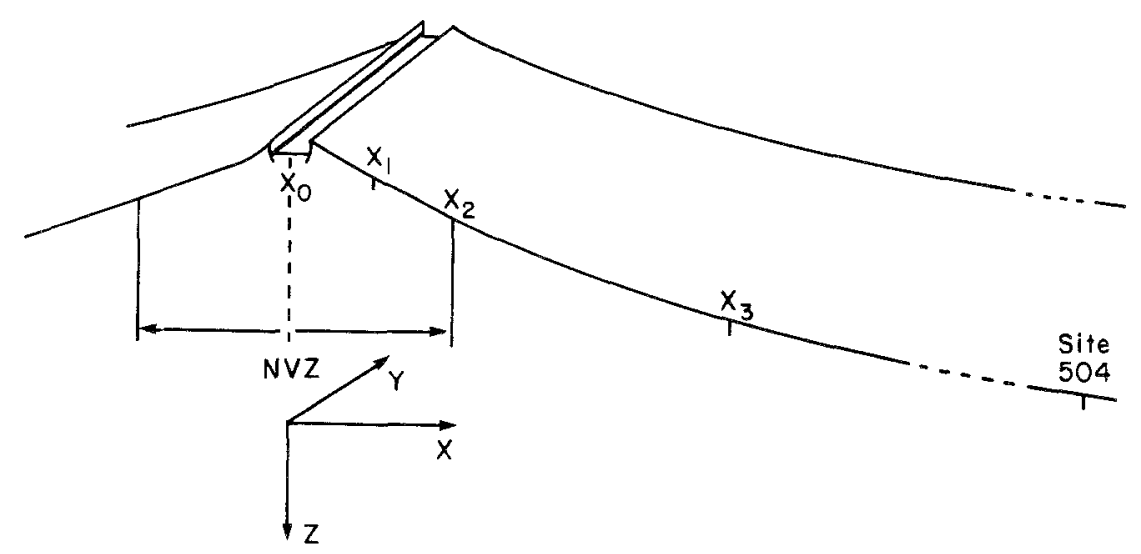

Fig. 17. Idealized view of the ridge axis and neo-volcanic zone (NVZ). At a half-spreading rate of $35 \mathrm{~mm} / \mathrm{year}$, the NVZ is proposed to be $1 \mathrm{~km}$ wide. 
as a time sequence. With the previous definition of the $\mathrm{NVZ}$, this $650 \mathrm{~m}$-thick volcanic pile observed in Hole 504B is necessarily built over a time interval of the order of 15,000 to 20,000 years at $3.5 \mathrm{~cm} \mathrm{yr}^{-1}$ (halfrate). The first lava extruded on-axis (now located at about $925 \mathrm{mbsf}$ ) is thus later covered by $650 \mathrm{~m}$ of MORB, as the crustal section sampled at Site 504 travels through the 500-m-wide NVZ at a velocity comparable to the spreading-rate. On-axis (point X0; Figure 17), the volcanic edifice can be considered as infinitely thin, as the oceanic basement is mainly constituted of sheeted-dikes. Similarly, the uppermost basalt unit sampled at the sediment-basement contact might be viewed as emplaced exactly at the external limit of the NVZ (point X2; Figure 17).

The 650 -m-thick volcanic pile thus represents a time-continuum for the period during which Site 504 was constructed. Due to (1) the alteration zonation observed in the rocks (Alt et al., 1986a, 1986b; Laverne, 1987) and geochemical log data (Anderson et al., 1989), (2) the relationship between alteration, hydrology and morphology (Pezard and Anderson, 1989), (3) the evidence for a paleo-seawater/basement interface within the Transition Zone (near $900 \mathrm{mbsf}$ ) from $\mathrm{Sr}$-isotopes and $\partial \mathrm{O}^{18}$ data (Friedrichsen, 1985; Alt et al., 1986a, 1986b), we will postulate in the following that the volcanic column sampled by Hole 504B was built by two main volcanic episodes, each starting with a massive eruption of magma. We will then check how this assumption fits with the previous episodic models deduced from seafloor observations.

\section{ACCRETION MODEL}

The first volcanic pulse (VS1) is proposed to cover the interval from the Transition Zone (at about $950 \mathrm{mbsf}$ ) to $580 \mathrm{mbsf}$, near the base of Unit 27. VS1 starts then with a massive eruption, having an upper surface today evidenced by the zonation of oxygen and strontium isotopes data (Friedrichsen, 1985; Alt et al., 1986a, 1986b). The second volcanic pulse (VS2) builds the section from $580 \mathrm{mbsf}$ to $325 \mathrm{mbsf}$, near the base of Unit 2D. The $50 \mathrm{~m}$-thick upper part of the basement will be considered as related to later episodes of accretion, and associated with far-reaching lava-flows extruded at- or nearthe-axis, when Site 504 was located out of the 'theoretical' NVZ ( $x>X 2$; Figure 17). This last point is compatible with the observation of flows travelling tens of kms in Iceland (Rittmann and Rittmann, 1976; Sidgursson and Sparks, 1978), or along MOR structures (Gente, 1987).

It might be noticed that, besides Unit 2D which is made of a 14 m-thick flow extruded after the end of the second volcanic episode, the $50 \mathrm{~m}$-thick interval at the top of the basement consists only of pillows and thin-flows that can be viewed as the distal expression of significant outpourings on-axis. In other DSDP Holes (Figure 13), the upper part of the crust has also often been observed to be made of pillows and thin-flows, and there is no actual example of a basement-sediment contact constituted with a massive unit. A similar relationship is derived from seafloor observations where pahoehoe and fluid lava are seen to predominate on-axis, and the percentage of pillows to increase away from the axis, as one 'travels' down the flanks toward the abyssal hills (Barone, 1989). In addition, the accretion of the upper part of the basement out of a theoretically narrow NVZ does not necessarily violate the magnetic constraint imposed by the existence of clear magnetic anomalies at the seafloor (Vine and Matthews, 1963). These upper $50 \mathrm{~m}$ represent only about $8 \%$ of the total thickness of the volcanic edifice, thereby probably smearing somewhat the magnetic signal without altering it significantly.

\section{MORPHOTECTONIC IMPLICATIONS}

Following the models of Kappel and Ryan (1986), and Gente (1987), a volcanic sequence starts with the massive outpouring of fluid basalt in a collapsed axial graben, eventually flooding it and spilling onto the flanks, depending on local topography and the overall magmatic budget. This massive flow would thus be located on top of lava corresponding to the end of the previous sequence, such as pillows and collapse-structures (Hekinian, 1984; Gente, 1987). This assemblage of a thick, impermeable cap on top of a heterogeneous, high-porosity zone creates the necessary structure to develop the under-pressured aquifer observed within Layer $2 \mathrm{~A}$ and Hole 504B.

The accretion of the volcanic section of Hole 504B can then be viewed as represented in Figures 18 and 19 with (1) flooding of the ESD by a massive unit, then (2) construction near-the-axis (between $\mathrm{X} 0$ and $\mathrm{X} 1$ ) of the lower part of the volcanic pile (VS1), followed by (3) a purely tectonic phase 
that is not constrained from the 504B data, and (4) renewed volcanism with the emplacement of Unit 27 at the beginning of VS2 (between X1 and X2) and (5) a new tectonic phase predating (6) the extrusion of Unit 2D at the onset of VS3 and (7) completion of the upper part of the volcanic pile out of the NVZ, at times again not constrained by this dataset.

A large number of implications might be derived from this simple accretion model. First of all, the expression in Hole 504B of the first massive outpouring of lava within the ESD (massive unit \#1 or MU1, Figure 18) is clearly different from that of the onset of VS2 (MU2, which is Unit 27). The necessity of fissuring and intruding MU1 (to extrude the rest of the volcanic pile on top of it) can be represented as in the cartoon of Figure 20. The propagation of an axial crack developing to become as large as 10 's of meters in width, thereby providing a path to the seafloor for magma, can be viewed as the source of the high-frequency resistivity (or porosity) record obtained in the Transition Zone, where near-vertical structures (dikes) alternate with subhorizontal features (MU1). A unit initially 10's of meters thick might therefore now appear as 200m-thick (from 4400 to 4600 mbdf) in cross-section, and constitute the observed transition from the underlying dikes to the overlying extrusives.

On the flanks, this massive unit (considered as MU1 on-axis) might as well play the role of MU2 for a volcanic pile already partly assembled, acting as a permeability barrier between seawater and the upper basement near point X1, for example (Figure 19). The duration of the tectonic phases (TP1 and TP2) cannot be constrained from the structural data alone. The exact location within the volcanic sequence of these stretching events is also difficult to identify. The model of Kappel and Ryan (1986) uses this tectonic period (time T4 in Figure 6) to stretch the ESD, which consequently constrains the emplacement of a massive unit at the onset of the next volcanic sequence (time $\mathrm{T} 1$ on Figure 6 ).

In a somewhat different way, Macdonald and Fox (1988) associate the existence of an ESD with the presence of a crustal magma chamber due to a lack of local support in the axial domain. A small and elongated caldera is thus supposed to develop as new magma is injected within the crust, potentially pressurizing the already existing chamber, and contribut- ing to the extrusion of colder, more differentiated magma in a syringe-like fashion. This extrusion, probably as pillows (Bonatti and Harrison, 1988), occurs prior to that of the massive unit. The onset of a volcanic sequence would then be characterized in this case by the extrusion of pillows, followed by massive outpourings of fluid lavas.

According to the simple geometrical model proposed in Figure 19, a pillow emplaced on-axis (solid dot; Figure 21) gets progressively buried with increasing time until completion of the accretion process, and ends up located near the base of the volcanic pile when observed off-axis in the case of Site 504, for example. In contrast, a pillow emplaced at X1 (open dot; Figure 21) would end up located at an intermediate depth, once out of the NVZ. Due to the (potential) large surface area of massive units, the part emplaced near-the-axis is bound to be buried by subsequent extrusions, whereas that emplaced off-axis (near X2, for example) contributes to the construction of the upper part of a crustal column. A structural tilt of these units might thus be expected from the present model (Figure 21), which could be tested in the future by the drilling of a series of nearby holes aligned in a direction orthogonal to the ridge crest. Such a tilt was predicted (Palmasson, 1973; Cann, 1974) or observed in ophiolite sequences (Rosencrantz, 1983) in the past.

\section{HYDROLOGICAL IMPLICATIONS}

In an analogy with Unit $3 \mathrm{~A}$ (the site of an underpressured aquifer) and Unit 2D (MU3), the pillows of Unit 28 underlying Unit 27 (MU2) can be interpreted as the site of a paleo-aquifer created near the axis, in agreement with the high fracture-porosity computed at this depth by Pezard and Anderson (1989; Figure 8) and the high fracture-density observed by Newmark et al., (1985) on BHTV images. This heterogeneous, high-porosity zone is probably rapidly sealed during hydrothermal alteration near the ridge-axis. The thick flow of Unit 27 consequently trapped warm $\left(150^{\circ} \mathrm{C}\right.$; Alt et al., 1986a, 1986b) evolved fluids below it, facilitating alteration and fracture sealing in the underlying rocks. It is within this axial domain (from X0 to X1; Figure 17) that black-smokers are observed, associated with open-circulation of fluids between the crust and the ocean. As this section is later buried by additional volcanism, it corresponds to the lower section of the 


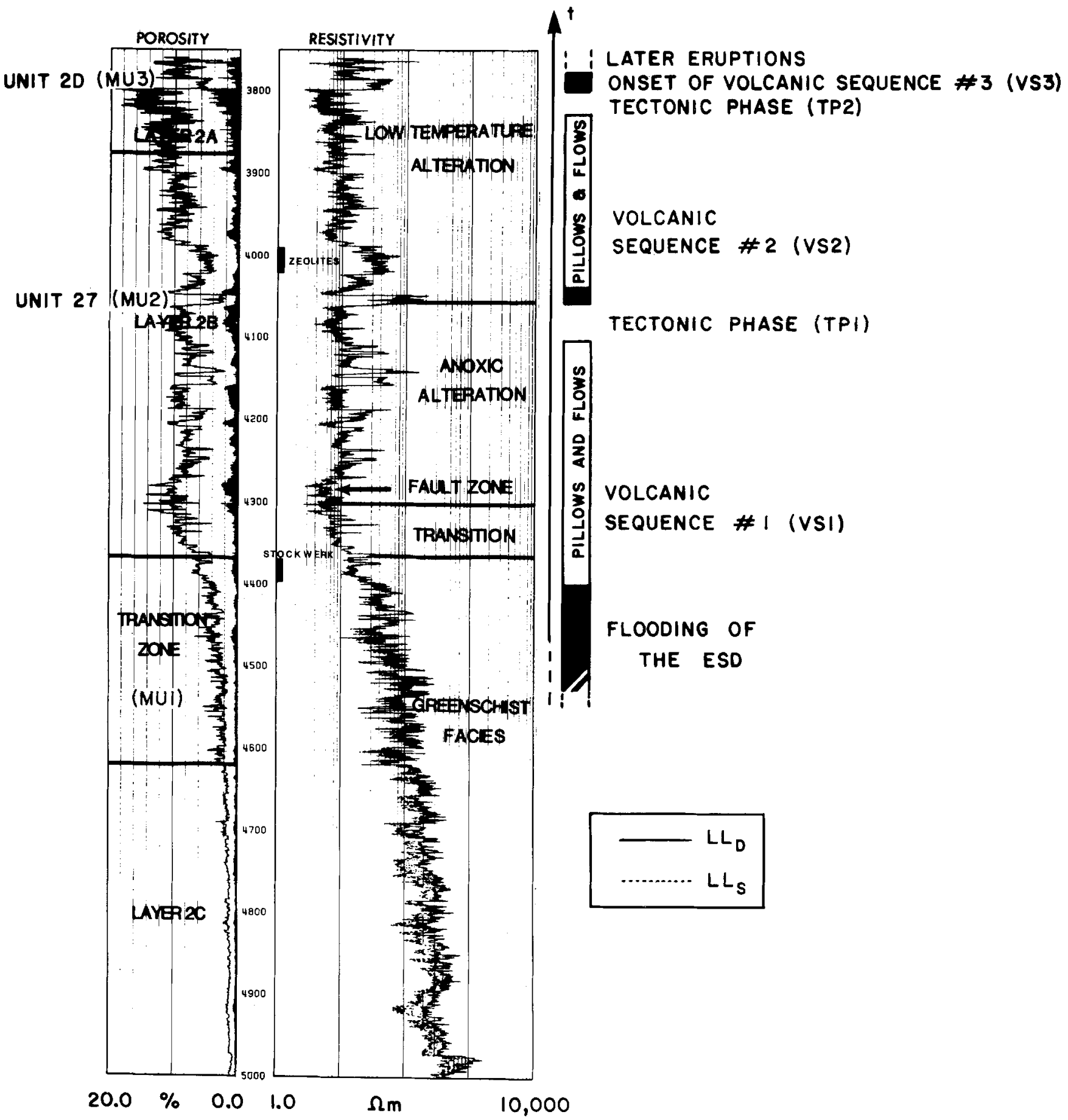

Fig. 18. Proposed accretion model for the volcanic section penetrated in Hole 504B. The time increases with decreasing depth.

volcanic edifice. Consequently, relicts of blacksmoker activity may not be studied off-axis with shallow basement holes. This result is consistent with observations from ophiolites, where massive sulfide deposits generally occur in the lower volcanic section (Adamides, 1987).
Similarly, the extrusion of MU1 within the axial graben can be viewed as the presence of a permeability barrier between the upper crust and the ocean. The emplacement of such a permeability-barrier near the axis offers as well a means to explain the two first phases of greenschist alteration observed in the lower 


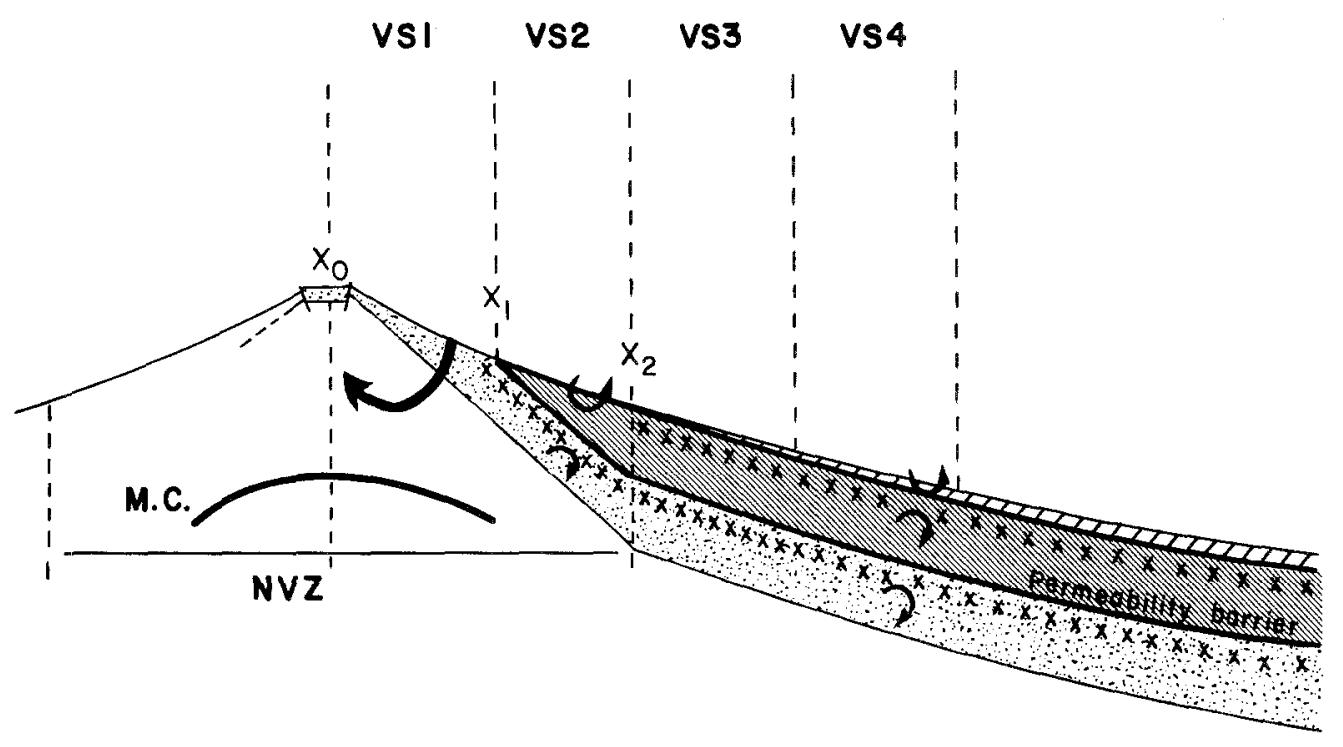

Fig. 19. Composite sketch representing (not at scale) the progressive accretion of a given vertical volcanic column (such as Site 504, for example), being created near the ridge-axis, then growing in thickness with time as it travels through the neo-volcanic zone (NVZ). The arrows represent fluid circulation within the crust, and MC stands for magma chamber. The extrusive part of the crust is about 650 -In thick, and the NVZ of the order of one-km wide (e.g. this is not a 2-D cross-section, but rather a series of instantaneous vertical structural profiles presented side-by-side in order to describe the progressive accretion process generated on-axis in the form of a depth-time diagram).

part of the hole (1) with early reactions at temperatures up to $200-250{ }^{\circ} \mathrm{C}$ involving partially reacted and $\mathrm{Mg}$-bearing seawater in a relatively open system, then (2) at even higher temperatures (up to $380^{\circ} \mathrm{C}$ ) with more evolved, Mg-depleted, metal-, Si-, and $\mathrm{O}^{18}$-enriched upwelling hydrothermal fluids in an environment more restricted to seawater access. The sealing of this interval is today observed with packer experiments (Becker et al., 1989) or the analysis of acoustic velocity profiles (Moos et al., 1990), particularly that of shear-wave propagation.

After sealing of the lower basement from oceanwaters by Unit 27 (Figure 19), the upper part of the volcanic pile (built by VS2, VS3, etc.) is only exposed to the heat conducted through Unit 27, thereby not directly to that transported by hydrothermal fluids coming from below. Although the presence of lower temperature phases of alteration in the upper part of the basement is evidence for fluid circulation, the lower temperatures of alteration constrained by the chemistry, the secondary mineralogy and the higher water-rock ratio than in VS1 may be direct consequences of this hydrological segmentation of the upper oceanic basement.

The hydrothermal history of the basement can thus be described as sketched in Figure 22. Near the ridge-axis (point $\mathrm{X} 0$ on Figure 17), the existing crustal section is mostly constituted of dikes and is permeated by warm fluids in a circulation system initially open to seawater recharge. With the emplacement of MU1, the upper crust is momentarily isolated from the percolation of ocean waters, thereby allowing for higher temperatures of alteration to develop within the dikes. The accretion proceeds with VS1, then stops for a period not constrained by this dataset, before volcanism resumes with Unit 27 (MU2) and VS2. Isolated fluidcirculation loops are thus created, and a reducing environment develops at low water-rock ratios in the lower part of the crust.

The alteration of the upper volcanics (VS2) progresses thus at lower temperatures and higher water/ rock ratios under conditions of open circulation of cold seawater. As hot, already reacted waters are trapped within the deeper crust, higher temperatures of alteration are allowed to develop. Similarly, the crustal section accreted during VS2 is soon also isolated from the open ocean by Unit $2 \mathrm{D}$, as the structure necessary to develop the underpressured aquifer that we observe today is created. VS 3 is also altered under open circulation of cold seawater. Finally, the deposition of a thick sedimentary cap on top of the volcanic edifice, and the development of chert at its base after $5.0 \mathrm{Ma}$ creates additional per- 
(a)

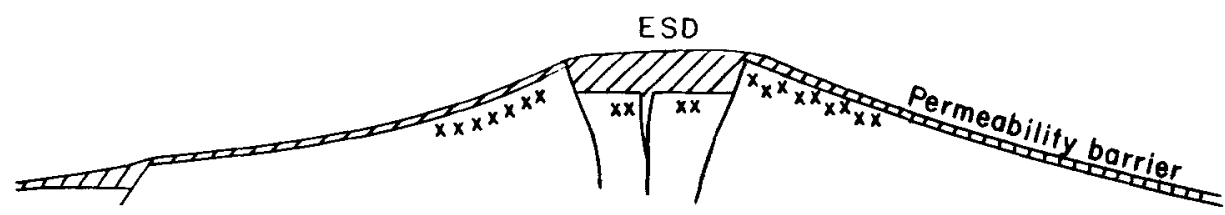

(b)

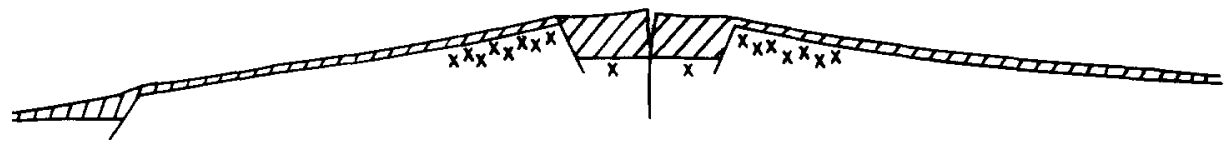

(c)

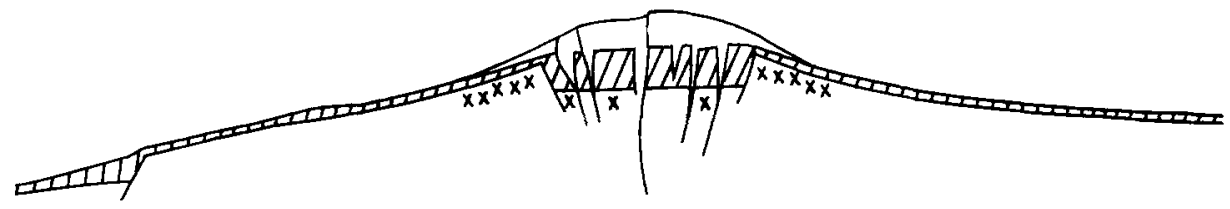

(d)

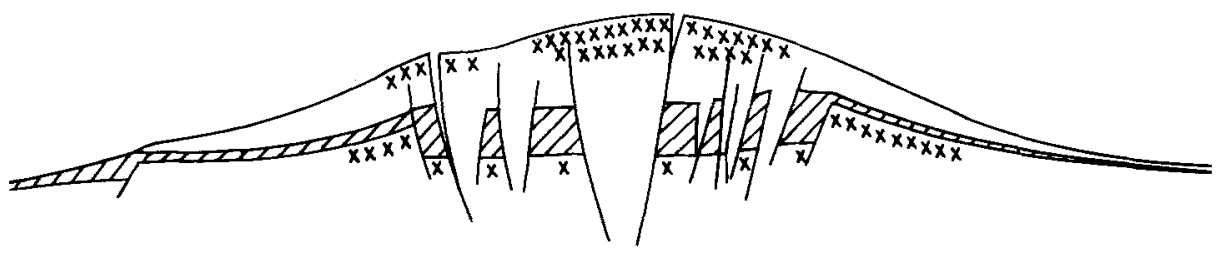

(e)

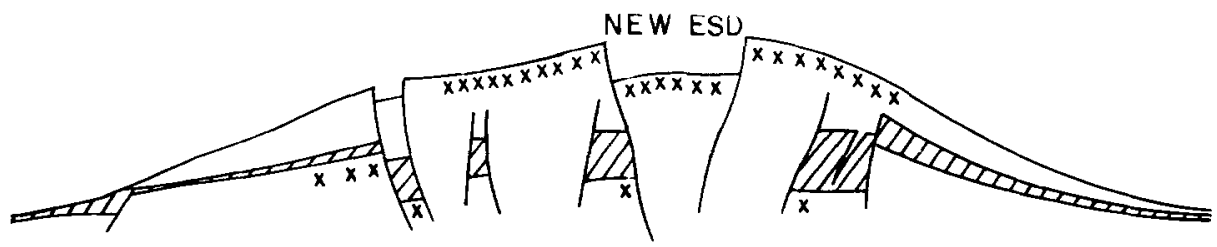

Fig. 20. Evolution with increasing time of the axial structure, starting with (a) the flooding of the ESD at the beginning of the first volcanic episode (VS1), and eventually overspilling on the ridge-flanks constituting an off-axis permeability barrier between underlying crustal rocks and water from the ocean, (b) fracturing on-axis of the massive unit emplaced within the ESD, then (c) renewed volcanism with splitting of the thick axial flow and (d) development of an axial crestal ridge until the end of the volcanic phase VSI and (e) collapse of a new axial graben.

meability barriers as the crust moves away from the ridge-axis. This simple morphotectonic accretion scenario consequently allows one to explain most of the observations made to date in Hole 504B in terms of structure, hydrology and alteration of the basaltic oceanic crust.

\section{Conclusions}

The geophysical data recorded in the volcanic section of Hole 504B are interpreted in terms of the non steady-state model of crustal accretion for intermediate spreading-rates of Kappel and Ryan (1986) and 


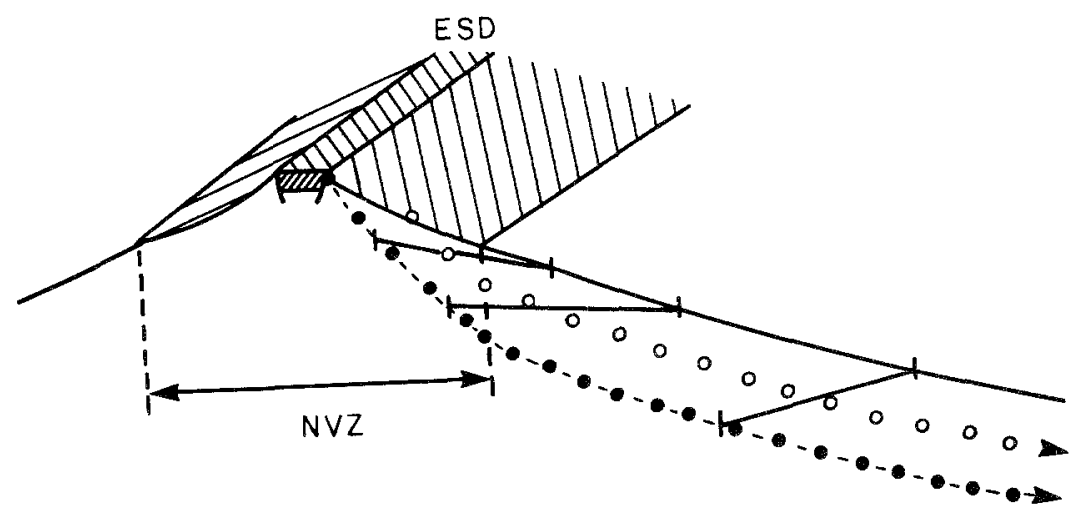

Fig. 21. Theoretical trajectories with time of (a) a pillow emplaced on-axis (solid dot), in the middle of the NVZ (open dot), and (b) of a massive unit. The extrusive part of the crust is $650-\mathrm{m}$ thick and the NVZ one-km wide.

Gente (1987) which, in turn, provides a framework to analyze the structural, hydrological, and mineralogical observations made in the hole over the past ten years. In the future, additional insights on accretion processes at Site 504 could be obtained from new geochemical analyses of rocks sampled from the core, on the basis of this study. In particular, the residence time within the crustal chamber of different magmas could be investigated and used as constraints on the present model (to compare that of Units $2 \mathrm{D}$ and $3 \mathrm{~A}$,
0.55 or 27 and 28 , for example). Due to the poor core recovery experienced in basement (averaging about $20 \%$ ), some units have been missed in the original lithostratigraphic description and others, proposed to be associated with a single crustal source in this document on the basis of log data (Figure 4), may not have been recognized as such initially. Resampling of the core and better yet, more complete sampling of the crust, is thus necessary prior to any further work.
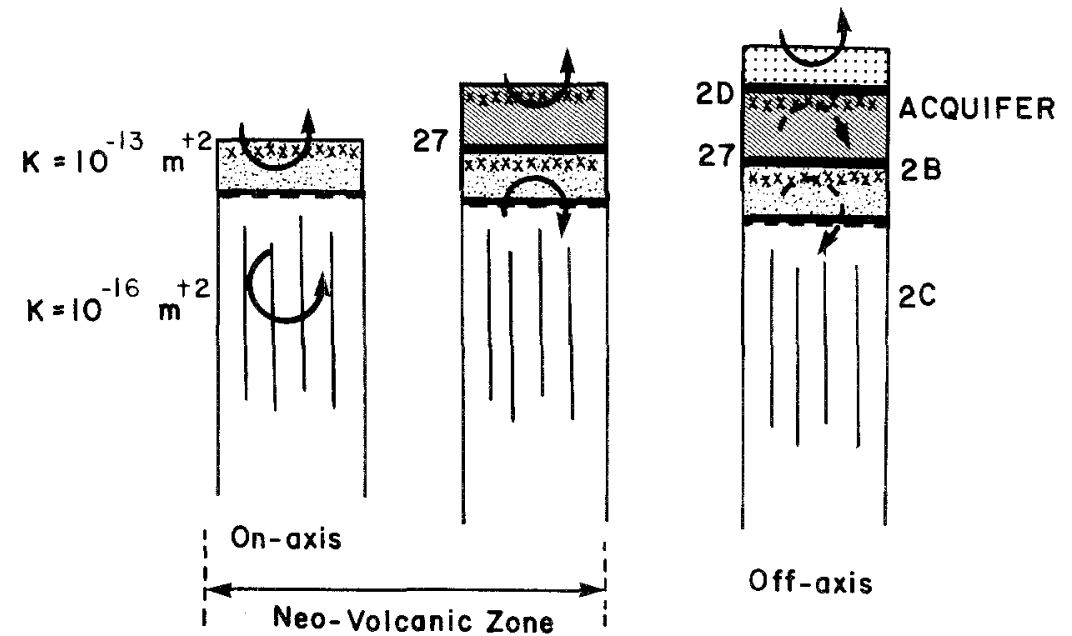

$(\simeq 0.5 \mathrm{~km})$

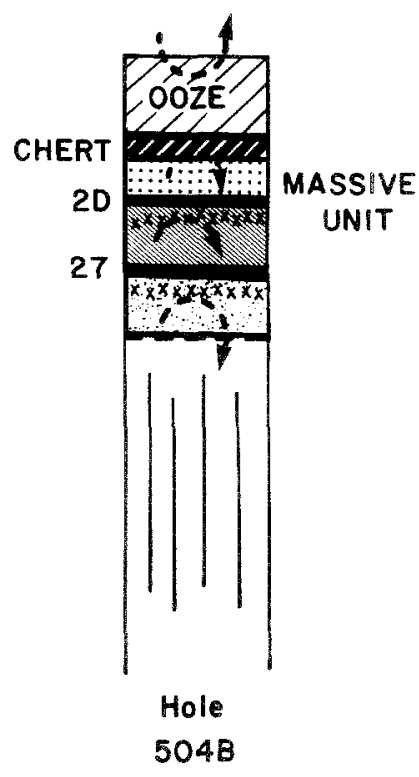

$(+5.9 \mathrm{ma})$

( 17.500 a)

$(\simeq 50.0000)$

Fig. 22. Hydrological evolution of the crust with respect to successive accretion phases. 
In addition, the recording of high-resolution electrical images of the borehole wall at the opportunity of the next return to Hole 504B within the ODP should provide valuable geometrical data (such as strike and dip) about extrusive and intrusive units, especially in the sheeted-dikes complex. Ultimately, the most stringent test of this model would consist in drilling a new hole in the near vicinity of 504B (within a few $100 \mathrm{~m}$ ), and in a direction orthogonal to the ridge axis.

\section{Acknowledgements}

This work would not have been possible without the numerous sea-going expeditions, either drilling or observing the seafloor, organized over the past twenty years, often as a result of international scientific cooperation, as well as the thousands of hours spent in the laboratory analysing the collected data. The authors are indebted to Kathrin Gillis, José Honnorez, Eric Humler, François-Dominique de Larouzière, Christine Laverne, Mike Lovell, Dan Moos, Margo Edwards and two anonymous reviewers for either fruitful discussions or critical reading of this manuscript. This work was supported by the National Science Foundation through the Joint Oceanographic Institution.

\section{References}

Adamides, N. G., 1987, Diverse Modes of Occurrence of Cyprus Sulfide Deposits and Comparison with Recent Analogues, Geol. Surv. Canada, paper 85-29, 153-168.

Alt, J. C., Laverne, C., and Muehlenbachs, K., 1985, Alteration of the Upper Oceanic Crust: Minerology and Processes in DSDP Hole 504B, Leg 83, Init. Repts. Deep Sea Drill. Proj. 83, 217-248.

Alt, J. C., Honnorez, J., Laverne, C., and Emmermann, R., 1986a, Hydrothermal Alteration of a 1-km Section through the Upper Oceanic Crust, DSDP Hole 504B: the Mineralogy, Chemistry and Evolution of Seawater-Basalt Interactions, J. Geophys. Res. 91, 309-335.

Alt, J. C., Muehlenbachs, K., and Honnorez, J., 1986b, An Oxygen Isotopic Profile through the Upper Kilometer of the Oceanic Crust, DSDP Hole 504B, Earth Planet. Sci. Lett. 80, 217-229.

Anderson, R. N., and Noltimier, H. C., 1973, A Model for the Horst and Graben Structure of Mid-Ocean Ridge Crests Based Upon Spreading Velocity and Basalt Delivery to the Oceanic Crust, Geophys. J.R. Astron. Soc. 34, 137-147.

Anderson, R. N., Langseth, M. G., and Sclater, J. G., 1977, The Mechanisms of Heat Transfer through the Floor of the Indian Ocean, J. Geophys. Res. 82, 3391-3409.

Anderson, R. N., and Zoback, M. D., 1982, Permeability, Underpressures, and Convection in the Oceanic Crust near the Costa Rica Rift, J. Geophys. Res. 87, 2860-2868.
Anderson, R. N., Honnorez, J., Becker, K. et al., 1985a, Init. Repts. Deep Sea Drill. Proj. 83.

Anderson, R. N., O'Malley, H., and Newmark, R. L., 1985b, Use of Geophysical Logs for Quantitative Determination of Fracturing, Alteration, and Lithostratigraphy in the Upper Oceanic Crust, DSDP Holes 504B and 556, Init. Repts. Deep Sea Drill. Proj. 83, 443-478.

Anderson, R. N., Zoback, M. D., Hickman, S. H., and Newmark, R. K., 1985c, Permeability versus Depth in the Upper Oceanic Crust: in situ Measurements in DSDP Hole 504B, Eastern Equatorial Pacific, J. Geophys. Res. 90, 3659-3669.

Anderson, R. N., Malpas, J., and Alt, J. C., 1989, Integrated Mass Fluxes from Geochemical Well-Logs in Hole 504B, Costa Rica Rift, Eastern Equatorial Pacific, in: Becker, K., and Sakai, H., (eds.), Proceedings of ODP, Scientific Results 111, 147-160, Ocean Drilling Program, College Station, Texas.

Archie, G. E., 1942, The Electrical Resistivity Log as an Aid in Determining Some Reservoir Characteristics, J. Pet. Technol. 5, $1-8$.

Atwater, T. M., and Mudie, J. D., 1968. Block Faulting on the Gorda Rise, Science 159, 729-731.

Atwater, T. M., and Mudie, J. D., 1973, Detailed Near-Bottom Geophysical Study of the Gorda Rise, J. Geophys. Res. 78, 8665-8686.

Autio, L. K., and Rhodes, J. M., 1983, Costa Rica Rift Zone Basalts: Geochemical and Experimental Data from a Possible Example of Multistage Melting, Initial Repts. Deep Sea Drill. Proj. 69, 729-745.

Ballard, R. D., Francheteau, J., Juteau, T., Rangin, C., and Normark, W., 1981, The East Pacific Rise at $21^{\circ} \mathrm{N}$ : the Volcanic, Tectonic and Hydrothermal Processes of the Central Axis, Earth Planet. Sci. Lett. 55, 1-10.

Barone, A. M., 1989, Morphotectonic Evolution of Subsea Volcanoes near the Boundary of Separating Plates. Examples from Lifting and Spreading Stages, $\mathrm{PhD}$ Thesis, Columbia University, New York.

Barrett, T. J., 1983, Strontium and Lead Isotope Composition of Some Basalts from DSDP Hole 504B, Costa Rica Rift, Leg 69 and 70, Initial Repts. Deep Sea Drill. Proj. 69, 643-650.

Barrett, T. J., and Friedrichsen, H., 1983, Oxygen and Hydrogen Isotope Composition of Some Basalts from DSDP Hole 504B, Costa Rica Rift, Leg 69-70, Initial Repts. Deep Sea Drill. Proj. 69, 637-642.

Becker, K., 1985, Large-Scale Electrical Resistivity and Bulk Porosity of the Oceanic Crust, DSDP Hole 504B, Costa Rica Rift, Initial Repts. Deep Sea Drill. Proj. 83, 419-427.

Becker, K., Sakai, H. et al., 1989, Drilling Deep into Young Oceanic Crust, Hole 504B, Costa Rica Rift, Rev. of Geophys. 27, 79-102.

Bonatti, E., and Harrison, C. G. A., 1988, Eruption Styles of Basalt in Oceanic Spreading Ridges and Seamounts: Effect of Magma Temperature and Viscosity, J. Geophys. Res. 93, 29672980.

Cann, J. R., 1968, Geological Processes at Mid-Ocean Ridges Crests, Geophys. J.R. Astron. Soc. 15, 331-341.

Cann, J. R., 1974, A model for oceanic crust developed, Geophys. J. R. Astron. Soc., 39, 169-187.

Cann, J. R., Langseth, M. G., Honnorez, J., Von Herzen, R. P., White, S. M. et al., 1983, Initial Repts. Deep Sea Drill. Proj. 69.

Choukroune, P., Francheteau, J., and Hekinian, R., 1984, Tectonics of the East Pacific Rise near $12^{\circ} 50^{\prime} \mathrm{N}$ : a Submersible Study, Earth Planet. Sci. Lett. 68, 115-127. 
Christensen, N. I., and Salisbury, M. H., 1975, Structure and Constitution of the Lower Oceanic Crust, Rev. Geophys. and Space Phys. 13, 57-86.

Collette, B. J., Verhoof, J., and Mulder, A. F. J. de, 1980, Gravity and a Model of the Median Valley, J. Geophys. Res. 47, 91-98.

Costa Rica Rift United Scientific Team (CRRUST), 1972, Geothermal Regimes of the Costa Rica Rift, East Pacific, Investigated by Drilling, DSDP-IPOD Legs 68, 69, and 70, Geol. Soc. Am. Bull. 93, 862-887.

Cox, C. S., 1971, The Electrical Conductivity of the Oceanic Lithosphere. In The Structure and Physical Properties of the Earth's Crust, Geophys. Mono. Ser. 14, American Geophysical Union, Washington, 227-234.

Cox, C. S., Constable, S. C., Chave, A. D., and Webb, S. C., 1986, Controlled-Source Electromagnetic Sounding of the Oceanic Lithosphere, Nature 320, 53-54.

Crane, K., 1978, Structure and Tectonics of the Galapagos Inner Rift, $86^{\circ} 10^{\prime} \mathrm{N}, J$. Geology 86, 715-730.

CYAMEX Scientific Team: Francheteau, J., Needham, H. D., Choukroune, P., Juteau, J., Seguret, M., Ballard, R. D., Fox, P. J., Normark, W. R., Carranza, A., Cordoba, D., Guerrero, J., and Rangin, C., 1981, First Manned Submersible Dives on the East Pacific Rise at $21^{\circ} \mathrm{N}$, Mar. Geophys. Res. 4, 345-379.

Daignières, M., Courtillot, V., Bayer, R., and Tapponnier, P., 1975, A Model for the Evolution of the Axial Zone of MidOcean Ridges as Suggested by Icelandic Tectonics, Eorth Planet. Sci. Lett. 26, 222-232.

Davis, E. E., and Lister, C. R. B., 1977, Tectonics Structures on the Juan de Fuca Ridge, Geol. Soc. Amer. Bull. 88, 346-363.

Deffeyes, K. S., 1970, The Axial Valley: A Steady-State Feature of the Terrain. In: Johnson, H., and Smith, B. L., (eds.), Megatectonics of Continents and Oceans, Rutgers U. Pr., New Brunswick, 194-222.

Donnelly, T., Francheteau, J., et al., 1979, Initial Repts. Deep Sea Drill. Proj. 51, 52, 53.

Edmond, J. M., Measures, C., McDuff, R. E., Chan, L. H., Collier, R., and Grant, B., 1979, Ridge Crest Hydrothermal Activity and the Balances of the Major and Minor Elements in the Ocean, Earth and Planet. Sci. Lett. 46, 1-18.

Edwards, M. H., 1991, The morphotectonic fabric of the East Pacific Rise: implications for fault generation and crustal accretion. PhD Thesis, Columbia Univ., New York.

Ellis, D. V., 1987, Well logging for earth scientists, Elsevier, New York.

Emerman, S. H., and Turcotte, D. L., 1984, The Mid-Ocean Ridge Axial Valley as a Steady-State Neck, Earth Planet. Sci. Lett. 71, 141-146.

Emmermann, R., 1985, Basement Geochemistry, Hole 504B, Initial Repts. Deep Sea Drill. Proj. 83, 183-199.

Fehn, U., Green, K. E., Von Herzen, R. P., and Cathles, L. M., 1983, Numerical Models for the Hydrothermal Field at the Galapagos Spreading Center, J. Geophys. Res. 88, 1033-1048.

Francheteau, J., 1983, The Oceanic Crust, Scien. Am. 249, 114129.

Friedrichsen, H., 1985, Strontium, Oxygen and Hydrogen Isotopes Studies on Primary and Secondary Minerals in Basalts from the Leg 83 Section of DSDP Hole 504B, Costa Rica Rift, Initial Repts. Deep Sea Drill. Proj. 83, 289-296.

Gable, R., Morin, R. H., and Becker, K., 1989, The Geothermal State of Hole 504B: ODP Leg 111 Overview, in: Becker, K., and Sakai, H., (eds.), Proceedings of ODP, Scientific Results 111, Ocean Drilling Program, College Station, Texas, 87-96.
Gass, I. G., and Smewing, J. D., 1973, Intrusion, Extrusion, and metamorphism at Constructive Margins: Evidence from the Troodos Massif, Cyprus, Nature 242, 26-29.

Gente, P., Auzende, J. M., Renard, V., Fouquet, Y., and Bideau, D., 1986, Detailed Geological Mapping by Submersible of the East Pacific Rise Axial Graben near $13^{\circ} \mathrm{N}$, Earth Planet. Sci. Lett. 78, 224-236.

Gente, P., 1987, Etude Morphostructurale Comparative des Dorsales Océaniques à Taux d'Expansion Variés, in: Thèse de Doctorat, Université de Bretagne Occidentale, Brest.

Harrison, C. G. A., 1968, Formation of Magnetic Anomaly Patterns by Dyke Injection. J. Geophys. Res. 73, 2137.

Harrison, C. G. A., 1974, Tectonics of Mid-Ocean Ridges, Tectonophysics 22, 301-310.

Harrison, C. G. A., and Stieltjes, L., 1977, Faulting within the Median Valley, Tectonophysics 38, 137-144.

Haymon, R. M., and Koski, R. A., 1987, A 3-D Model of Along-Axis Hydrothermal Circulation, Discharge, and Mineralization in the Bayda Hydrothermal System, Northern Oman Ophiolite, EOS, Trans. Am. Geophys. Union 68, 1545.

Heezen, B. C., 1960, The Rift in the Ocean Floor, Scien. Am. 203, $98-110$.

Heezen, B. C., and Ewing, M., 1963, The Mid-Ocean Ridge, in: Hill, R. N. (ed.), The Sea, Wiley-Interscience, New York, $388-410$.

Hekinian, R., 1984, Undersea Volcanoes, Scien. Am. 251, 46-55.

Hess, H. H., 1959, Nature of the Great Ocean Ridges. In: Sears, M. (ed.), International Oceanographic Congress preprints, Washington, D.C., American Association for the Advancement of Science, 33-34.

Hess, H. H., 1965, Mid-Ocean Ridges and Tectonics of the Sea-Floor. In: Wittard, W. F., and Bradshaw, R., (eds.), Submarine Geology and Geophysics, Butterworths, London, $317-$ 333.

Hill, D. G., 1972, Laboratory Analysis of Electrical Anisotropy in Precambrian Rocks, Geophys. 37, 6.

Hobart, M. A., Langseth, M. G., and Anderson, R. N., 1985, A Geophysical and Geothermal Survey on the South Flank of the Costa Rica Rift: Sites 504 and 505, Initial Repts. Deep Sea Drill. Proj. 83, 379-404.

Honnorez, J., Laverne, C., Hubberten, H. W., Emmermann, R., and Muehlenbachs, K., 1983, Alteration Processes in Layer 2 Basalts from DSDP Hole 504B, Costa Rica Rift, Initial Repts. Deep Sea Drill. Proj. 69, 509-546.

Houtz, R., and Ewing, J., 1976, Upper Crustal Structure as a Function of Plate Age, J. Geophys. Res. 81, 2490-2498.

Hubberten, H. W., Emmermann, R., and Puchelt, H., 1983, Geochemistry of Basalts from Costa Rica Rift Sites 504 and 505 (DSDP Legs 69 and 70), Initial Repts. Deep Sea Drill. Proj. 69, $791-804$.

Hyndman, R. D., Von Herzen, R. P., Erickson, A. J., and Jolivet, J., 1976, Heat-Flow Measurements in Deep Crustal Holes on the Mid-Atlantic Ridge, J. Geophys. Res. 81, 4053-4060.

Hyndman, R. D., and Salisbury, M. H., 1983, The Physical Nature of the Oceanic Crust on the Mid-Atlantic Ridge, DSDP Hole 395A, Initial Repts. Deep Sea Drill. Proj. 78B, 839-848.

Kappel, E. S., and Ryan, W. B. F., 1986, Volcanic Episodicity and a Non-Steady State Rift Valley along Northeast Pacific Spreading Centers: Evidence from Sea MARC I, J. Geophys. Res. 91, 13925-13940.

Keller, G. V., and Frischknecht, F. C., 1966, Electrical Methods in Geophysical Prospecting, Pergamon Press, Oxford. 
Kidd, R. G. W., 1977, A Model for the Process of Formation of the Upper Oceanic Crust, Geophys. J.R. Astron. Soc. 50, 149183.

Klein, E. M., and Langmuir, C. H., 1987, Global Correlations of Ocean Ridge Basalt Chemistry with Axial Depth and Crustal Thickness, J. Geophys. Res. 92, 8089-8115.

Klitgord, K. D. and Mudie, J. D., 1974, The Galapagos Spreading Center: a Near-Bottom Geophysical Survey, Geophys. J.R. Astron. Soc. 38, 563-586.

Koide, H., and Bhattacharji, S., 1975, Mechanistic Interpretation of Rift Valley Formation, Science 189, 791-793.

Kopietz, J., Becker, K., and Hamano, Y., 1989, Temperature Measurements at Site 395, ODP Leg 109. In: Bryan, W. B., and Juteau, T., (eds.), Proceedings of ODP, Scientific Results 109, Ocean Drilling Program, College Station, Texas, 197203.

Lachenbruch, A. H., 1973, A simple Mechanical Model for Oceanic Spreading Centers, J. Geophys. Res. 78, 3395-3417.

Lachenbruch, A. H., 1976, Dynamics of a Passive Spreading Center, J. Geophys. Res. 81, 1883-1902.

Langmuir, C. H., Bender, J. F., and Batiza, R., 1986, Petrologic and Tectonic Segmentation of the East Pacific Rise, $5^{\circ} 30^{\prime} \mathrm{N}$ $14^{\circ} 30^{\prime} \mathrm{N}$, Nature $322,422-429$

Laughton, A. S., and Searle, R. C., 1979, Tectonic Processes on Slow Spreading Ridges. In: Talwani et al., (eds.), Deep drilling results in the Atlantic Ocean, American Geophysical Union, Washington, 15-32.

Laverne, C., 1987, Les Altérations des Basaltes en Domaine Océanique. Minéralogie, Pétrologie et Géocshimie d'un Système Hydrothermal: le Puits 504B, Pacific Oriental, in Thèse d'Etat, Marseille.

Lewis, B. R. T., 1979, Periodicities in Volcanism and Longitudinal Magma Flow on the East Pacific Rise at $23^{\circ} \mathrm{N}$, Geophys. Res. Lett. 6, 753-756.

Lister, C. R. B., 1972, On the Thermal Balance of Mid-Ocean Ridges, Geophys. J.R. Astron. Soc. 26, 515-535.

Lister, C. R. B., 1974, On the Penetration of Water into Hot Rock, Geophys. J.R. Astron. Soc. 39, 465-509.

Lonsdale, P., 1977, Deep-Tow Observations at the Mounds Abyssal Hydrothermal Field, Galapagos Rift, Earth Planet. Sci. Lett. 36, 92-110.

Lonsdale, P., 1977, Structural Geomorphology of a Fast-Spreading Rise Crest: The East Pacific Rise near $3^{\circ} 25^{\prime} \mathrm{S}$, Mar. Geophys. Res. 3, 251-293.

Lonsdale, R., and Klitgord, K. D., 1978, Structure and Tectonic History of the Eastern Panama Basin, Geol. Soc. Am. Bull. 89, 981-999.

Macdonald, K. C., 1982, Mid-Ocean Ridges: Fine-Scale Tectonic, Volcanic and Hydrothermal Processes within the Plate Boundary Zone, Ann. Rev. Earth Planet. Sci. 10, 155-190.

Macdonald, K. C., 1983, Crustal Processes at Spreading Centers, Rev. of Geophys. and Space Phys. 21, 1441-1454.

Macdonald, K. C., and Luyendyk, B. P., 1977, Deep-tow studies of the structure of the Mid-Atlantic ridge crest near lat $37^{\circ} \mathrm{N}$, Geol. Soc. Amer. Bull. 88, 621-636.

Macdonald, K. C., and Atwater, T. M., 1978, Evolution of Rifted Ocean Ridges, Earth Planet. Sci. Lett. 39, 319-327.

Macdonald, K. C., Miller, S. P., Luyendyk, B. P., Atwater, T. M. and Shure, L., 1983, Investigation of a Vine-Matthews Magnetic Lineation from a Submersible: The Source and Character of Marine Magnetics Anomalies, J. Geophys. Res. 88, 3403-3418.

Macdonald, K. C., Sempere, J. C., and Fox, P. J., 1984, East Pacific Rise from Sisqueiros to Orozco Fracture Zones: Along-
Strike Continuity of Axial Neovolcanic Zone, Structure and Evolution of Overlapping Spreading Centers, J. Geophys. Res. 89, 6049-6069.

Macdonald, K. C., and Fox, P. J., 1988, The Axial Summit Graben and Cross-Sectional Shape of the East Pacific Rise as Indicator of Axial Magma Chambers and Recent Volcanic Eruptions, Earth Planet. Sci. Lett. 88, 119-131.

Melson, W. G., and Rabinowitz, P. D., 1979, Initial Repts. Deep Sea Drill. Proj. $\mathbf{4 5}$

Menard, H. W., 1960, The East Pacific Rise, Science 132, 1737 1746.

Menard, H. W., 1967, Seafloor Spreading, Topography and the Second Layer, Science 158, 923-924.

Moores, E. M., 1982, Origin and Emplacement of Ophiolites, Rev. Geophys. 20, 735-760.

Moos, D., Pezard, P. A., and Lovell, M. A., 1990, In Situ Elastic Properties of Basalts from the Upper Oceanic Crust in DSDP and ODP Drillholes, J. Geophys. Res. 95, 9189-9208.

Morton, J. L., Sleep, N. H., 1985, A Mid-Ocean Ridge Thermal Model: Constraints on the Volume of Axial Hydrothermal Heat Flux, J. Geophys. Res. 90, 11345-11353.

Natland, J. H., Adamson, A. C., Laverne, C., Melson, W. G., and O'Hearn, T., 1983, A Compositionally nearly Steady-State Magma Chamber at the Costa Rica Rift: Evidence from Basalt Glass and Mineral Data, DSDP, Initial Repts. Deep Sea Drill. Proj. 69, 811-858.

Needham, H. D., and Francheteau, J., 1974, Some Characteristics of the Rift Valley in the Atlantic Ocean near $36^{\circ} 48^{\prime}$ North, Earth Planet. Sci. Lett. 22, 29-43.

Nehlig, P., and Juteau, T., 1988, Flow Porosities, Permeabilities and Preliminary Data on Fluid Inclusions and Fossil Thermal Gradients in the Crustal Sequence of the Semail Ophiolite (Oman), Tectonophysics 151, 199-222.

Nelson, K. D., 1981, A Simple Thermal-Mechanical Model for Mid-Ocean Ridge Topographic Variation, Geophys. J.R. Astron. Soc. 65, 19-30.

Newmark, R. L., Anderson, R. N., Moos, D., and Zoback, M. D., 1985, Sonic and Ultrasonic Logging of Hole 504B and its Implications for the Structure, Porosity, and Stress Regime of the Upper $1 \mathrm{~km}$ of the Oceanic Crust, Initial Repts. Deep Sea Drill. Proj. 83, 479-510.

Normark, W. R., 1976, Delineation of the Main Extrusion Zone of the East Pacific Rise at Latitude $21^{\circ} \mathrm{N}$, Geology 4, 681-685.

Olhoeft, G. R., 1981, Electrical Properties of Rocks. In Touloukian, Y. S., Judd, W. R., and Roy, R. F. (eds.), Physical Properties of Rocks and Minerals, McGraw-Hill, New York, 257-330.

Palmasson, G., 1973, Kinematics and Heat Flow in a Volcanic Rift Zone, with Application to Iceland, Geophys. J.R. Astron. Soc. 33, 451-481.

Parkhomenko, E. I., 1967, Electrical properties of rocks, G. V. Keller trans. \& ed., Plenum, New York.

Pezard, P. A., 1990, Electrical Properties of MORB, and Implications for the Structure of the Upper Oceanic Crust at DSDP Site 504, J. Geophys. Res. 95, 9237-9264.

Pezard, P. A., and Anderson, R. N., 1989, Morphology and Alteration of the Upper Oceanic Crust from in situ Electrical Experiments in DSDP Hole 504B, in Becker, K., and Sakai, H. (eds.), Proceedings of ODP, Scientific Results 111, Ocean Drilling Program, College Station, Texas, 133-146.

Pezard, P. A., and Anderson, R. N., 1990, In situ Measurements of Electrical Resistivity, Formation Anisotropy, and Tectonic Context, Trans. SPWLA, Ann. Logging Symposium, 31st. 
Piper, J. D. A., and Gibson, I. L., 1972, Stress Control of Processes at Extensional Plate margins, Nature Physical Science 238, 83-86.

Rangin, C., and Francheteau, J., 1981, Fine Scale Morphological and Structural Analysis of the East Pacific Rise, $21^{\circ} \mathrm{N}$ (Rita Project), Oceanologica Acta, Colloque Géologie des Océans, Paris 1980, 15-24.

Rea, D. K., 1975, Model for the Formation of Topographic Features of the East Pacific Rise Crest, Geology 3, $77-80$.

Rittmann, A., and Rittmann, L., 1976, Volcanoes, Putnam's Sons, New York, 29-33.

Robinson, P. T., Lewis, B. R. T., Flower, M. F. J., Salisbury, M. H., and Schminke, H. U., 1973, Crustal Accretion in the Gulf of California: A Medium-Rate Spreading Axis, Initial Repts. Deep Sea Drill. Proj., 65, 739-752.

Rosencrantz, E., 1983, The structure of sheeted dikes and associated rocks in the North Arm massif, Bay of Islands ophiolite complex, and the intrusive process at oceanic spreading centers. Can. J. Earth Sci., 20, 787-801.

Salisbury, M. H., Donnelly, T. W., and Francheteau, J., 1980, Geophysical Logging in DSDP Hole 417D, in: Donnelly, T., Francheteau, J., et al. (eds.), Initial Repts. Deep Sea Drill. Proj. 51, 52, 53, 705-713.

Schlumberger, C., 1920, Etude sur la prospection électrique du sous-sol, Gauthiers-Villars, Paris, p. 40.

Searle, R., 1984, Gloria Survey of the East Pacific Rise near $3.5^{\circ} \mathrm{S}$ : Tectonic and Volcanic Characteristics of a Fast Spreading Mid-Ocean Rise, Tectonophysics 101, 319-344.

Shankland, T. J., and Waff, H. S., 1974, Conductivity in FluidBearing Rocks, J. Geophys. Res. 79, 4863-4868.

Sidgursson, H., and Sparks, S. R. J., 1978, Lateral Magma Flow within Rifted Icelandic Crust, Nature 274, 126-130.

Sleep, N. H., 1969, Sensitivity of Heat Flow and Gravity to the Mechanism of Sea-Floor Spreading, J. Geophys. Res. 74, 542549.

Sleep, N. H., and Rosendahl, B. R., 1979, Topography and
Tectonics of Mid-Oceanic Ridges Axes, J. Geophys. Res. 84, 6831-6839.

Sleep, N. H., and Wolery, T. J., 1978, Thermal and Chemical Constraints on Venting of Hydrothermal Fluids at Mid-Ocean Ridges, J. Geophys. Res. 83, 5913-5922.

Tapponnier, P., and Francheteau, J., 1978, Necking of the Lithosphere and the Mechanics of Slowly Accreting Plate Boundaries, J. Geophys. Res. 83, 3955-3970.

Usselmann, T. M., and Hodge, D. S., 1978, Thermal Control of Low-Pressure Fractionation Processes, J. Volcanol. Geotherm. Res. 4, 265-281.

van Andel, T. H., and Bowin, C. O., 1968, Mid-Atlantic Ridge between $22^{\circ}$ and $23^{\circ}$ North Latitude and the Tectonics of Mid-Ocean Ridges, J. Geophys. Res. 73, 1279-1298.

Vera, E., 1989, The Structure of 0- to 0.2-M.Y.-Old Oceanic Crust at $9^{\circ} \mathrm{N}$ on the East Pacific Rise from Expanded Spread Profiles, $P h D$ Thesis, Columbia University, New York.

Vine, F. J., and Matthews, D. H., 1963, Magnetic Anomalies over Oceanic Ridges, Nature 199, 947-949.

Whitmarsh, R. B., and Laughton, A. S., 1976, A Long-Range Sonar Study of the Mid-Atlantic Ridge Crest near $37^{\circ} \mathrm{N}$ (FAMOUS Area) and its Tectonic Implications, Deep Sea Research 23, 1005-1023.

Williams, D. L., Von Herzen, R. P., Sclater, J. G., and Anderson, R. N., 1974, The Galapagos Spreading Centre: Lithospheric Cooling and Hydrothermal Circulation, Geophys. J.R. Astron. Soc. 38, 587-608.

Williams, C. F., Narasimhan, T. N., Anderson, R. N., Zoback, M. D., and Becker, K., 1986, Convection in the Oceanic Crust: Simulation of Observations from DSDP Hole 504B, Costa Rica Rift, J. Geophys. Res. 91, 4877-4889.

Wyllie, R. J., Gregory, A. R., and Gardner, G. H. F., 1958, An Experimental Investigation of Factors Affecting Elastic Wave Velocities in Porous Media, Geophysics 23, 459-469.

Young, P. D., and Cox, C. S., 1981, Electromagnetic Active Source Sounding near the East Pacific Rise, Geophys. Res. Lett. 8, $1043-1046$. 